\title{
Effects of Rht17 in combination with Vrn-B1 and Ppd-D1 alleles on agronomic traits in wheat in black earth and non-black earth regions
}

Pavel Yu. Kroupin ${ }^{1,2}$, Gennady I. Karlov ${ }^{1,2}$, Ludmila A. Bespalova ${ }^{3}$, Elena A. Salina4, Anastasiya G. Chernook ${ }^{1,2}$, Nobuyoshi Watanabe ${ }^{5}$, Mikhail S. Bazhenov ${ }^{1,2}$, Vladimir V. Panchenko ${ }^{3}$, Lubov A. Nazarova ${ }^{6}$, Victor Ya. Kovtunenko ${ }^{3}$ and Mikhail G. Divashuk ${ }^{1,26^{*}}$ (i)

From Fifth International Scientific Conference "Plant Genetics, Genomics, Bioinformatics, and Biotechnology" (PlantGen2019) Novosibirsk, Russia. 24-29 June 2019

\begin{abstract}
Background: Plant height is an important wheat trait that is regulated by multiple genes, among which Rht is of the utmost value. In wheat, Rht-B1p (=Rht17) is a mutant allele of the Rht gene that encodes for a DELLA-protein and results in the development of gibberellin-insensitive plants with a dwarfing phenotype. The pleiotropic effects of dwarfing genes on yield are highly dependent on both the genetic background and the environmental conditions. In Russia, the Central Non-Black Earth Region and Krasnodar Krai are two economically important regions that require differing management for sustainable wheat production for food, feed and industry. The purpose of our study was to compare the pleiotropic effects of Rht-B1p on the main valuable agronomic traits in the $F_{3: 4}$ families of the spring bread wheat Chris Mutant/Novosibirskaya 67 in the genetic background of Vrn-B1a/ vrn-B1 (spring/winter phenotype) and Ppd-D1a/Ppd-D1b (insensitivity/sensitivity to photoperiod) alleles in a field experiment in Moscow and Krasnodar Krai.

(Continued on next page)
\end{abstract}

\footnotetext{
* Correspondence: divashuk@gmail.com

${ }^{1}$ Laboratory of Applied Genomics and Crop Breeding, All-Russia Research Institute of Agricultural Biotechnology, Timiryazevskaya str. 42, Moscow 127550, Russia

${ }^{2}$ Centre for Molecular Biotechnology, Russian State Agrarian University-

Moscow Timiryazev Agricultural Academy, Timiryazevskaya street, 49,

Moscow 127550, Russia

Full list of author information is available at the end of the article
}

(c) The Author(s). 2020, corrected publication 2020. Open Access This article is licensed under a Creative Commons Attribution 4.0 International License, which permits use, sharing, adaptation, distribution and reproduction in any medium or format, as long as you give appropriate credit to the original author(s) and the source, provide a link to the Creative Commons licence, and indicate if changes were made. The images or other third party material in this article are included in the article's Creative Commons licence, unless indicated otherwise in a credit line to the material. If material is not included in the article's Creative Commons licence and your intended use is not permitted by statutory regulation or exceeds the permitted use, you will need to obtain permission directly from the copyright holder. To view a copy of this licence, visit http://creativecommons.org/ licenses/by/4.0/. The Creative Commons Public Domain Dedication waiver (http://creativecommons.org/publicdomain/zero/1. 0/) applies to the data made available in this article, unless otherwise stated in a credit line to the data. 


\begin{abstract}
(Continued from previous page)
Results: Plant height was reduced on average by $21 \mathrm{~cm}(28 \%)$ and $25 \mathrm{~cm}$ (30\%), respectively; Ppd-D1a slightly strengthened the dwarfing effect in Moscow and mitigated it in Krasnodar Krai. Grain weight of the main spike was reduced by Rht-B1p in Moscow and to lesser extent in Krasnodar; Ppd-Dla and Vrn-Bla tended to partially compensate for this loss in Krasnodar Krai. Thousand grain weight was reduced on average by $5.3 \mathrm{~g}(16 \%)$ and $2.9 \mathrm{~g}$ (10\%) in Moscow and Krasnodar Krai, respectively, but was partially compensated for by Ppd-Dla in Krasnodar Krai. Harvest index was increased due to Rht-B1p by 6 and 10\% in Moscow and Krasnodar Krai, respectively. Rht-B1p resulted in a delay of heading by 1-2 days in Moscow. Ppd-D1a accelerated heading by 1 day and 6 days in Moscow and in Krasnodar Krai, respectively.

Conclusions: Rht-B1p could be introduced into wheat breeding along with dwarfing genes such as Rht-B1b and Rht-D1b. Special attention should be paid to its combination with Ppd-Dla and Vrn-Bla as regulators of developmental rates, compensators of adverse effects of Rht-B1p on productivity and enhancers of positive effect of Rht-B1p on harvest index.
\end{abstract}

Keywords: Wheat (Triticum aestivum), Dwarfing genes, Photoperiod-response genes, Vernalization genes, Rht, Ppd, Vrn, Harvest index

\section{Background}

Wheat is an important food crop and one of the main sources of calories for humanity. The main factor behind the significant increase in crop yield in the 40th-70th years of the twentieth century, the so-called "Green revolution", was the development of semi-dwarf wheat varieties (with shorter stature) through the introgression of allelic variants of $R h t$ genes, including $R h t-B 1 b$, which determine plant height and result in a semi-dwarf phenotype. Thanks to the expression of these alleles, it became possible to increase grain yield through better lodging resistance under irrigation and high doses of nitrogen fertilizers, leading to an increase in the number of grains in each spikelet and grain per unit area.

Wild-type alleles Rht-A1a, Rht-B1a, and Rht-D1a encode DELLA proteins that inhibit the growth of plant cells through negative regulation of the gibberellin signaling pathway, while the degradation of the DELLA protein is promoted by active forms of gibberellins [1]. The phenotypic manifestation of the wild-type allele $R h t-B 1 a$ is a tall plant; presently, at least 15 alleles of this gene are known, of which $R h t-B 1 c$ results in a dwarf phenotype, Rht-B1b, Rht-B1e, Rht-B1f, Rht-B1h, Rht-B1p a semi-dwarf phenotype, while plants with Rht-B1g, Rht$B 1$ i-1 are tall plants (overgrowth mutants) compared to the wild-type allele $R h t-B 1 a$ [2-6]. Alleles $R h t-B 1 b$ and Rht-B1e contain a premature stop codon, which is proposed to result in the translation of a form of DELLA protein resistant to proteolysis, and thus permanently inhibiting cell growth [2, 7]. Thus, the dwarfism of plants caused by such mutations of Rht-1 genes cannot be compensated by the use of exogenous gibberellic acid (GA). Previously we have shown that the dwarfing allele formerly named Rht17, now designated $R h t-B 1 p$, also contains a single-nucleotide substitution that leads to a premature stop codon, so this probably has a similar mechanism of action to other GA-insensitive alleles of Rht-B1.

Despite the similarities in the mechanism of action of GA-insensitive alleles of the Rht-B1 locus, their effect on plant height and distribution in the genetic regions vary considerably $[2,5,8-10]$. An excessively strong decrease in height is caused by Rht-B1c (about 50\%), which inhibits its widespread use in breeding practice [11, 12]. The most common Rht-B1b dwarfing allele leads to a moderate decrease in plant height in the range of 1025\% [13-15]. Locally distributed in Southern Europe is the allele $R h t-B 1 d$, which reduces height by $10-17 \%$ [12, 16]; in East Europe, Rht-B1e reduces height by $30 \%$ [8, 17, 18]; and in China, Rht-B1h produces a $10 \%$ height reduction (2). In plants bearing the $R h t-B 1 p$ allele, the effect of plant height reduction is $30-33 \%$ in the vegetation experiment in bread wheat $[7,19]$. It is known that the inheritance of $R h t-B 1 p$, like that of the dwarfing alleles with a moderate effect, Rht-B1b and Rht-B1e, is partially recessive relative to the dominant wild-type allele $R h t-B 1 a$ [7, 20-22].

Dwarfing alleles have an impact not only on plant height, but also have a pleiotropic effect on the timing of plant development and productivity elements. In dwarf plants, assimilate partitioning is improved, making possible the survival of a higher number of florets, thereby increasing the number of grains per spike and improving harvest index [11, 23]. However, GA-insensitivity caused by a number of dwarfing alleles of Rht-B1 leads to a decrease in the length of the coleoptile from 19 to 27\%, that prevents deep seeding in regions with insufficient soil moisture [19, 24-26]; and also to the development of grains with a lower mass $[15,27]$. The effect of dwarf plant genes depends on weather and climatic conditions as well as the genetic background [13, 15, 17, 27]. Therefore, it can be expected that the influence of different 
dwarfing alleles at the Rht-B1 locus on the elements of productivity will also be different in different growing conditions and in different genetic environments. The effect of Rht-B1p on elements of crop structure in spring bread wheat has not been studied and needs to be addressed.

The timing of the onset of such developmental phases as stem elongation, heading and flowering are important adaptive traits of wheat and are controlled by three different signaling pathways: the vernalization $(V R N)$, photoperiod (PPD), and earliness per se (EPS) pathways) [28-30]. Thus, the optimal combination of alleles of these genes plays a main role in the formation of phenological types of plants most suitable for and adapted to agroclimatic regions.

$V R N-1$ genes encoding MADS-box transcription factors are involved in the regulation of apical transition from the vegetative to reproductive phase [31, 32]. Of the three homologous genes VRN-A1, VRN-B1 and $V R N-D 1$, located on chromosomes $5 \mathrm{~A}, 5 \mathrm{~B}$ and $5 \mathrm{D}$ respectively, $V R N-A 1$ has the strongest influence on the phenotype and has an epistatic effect relative to $V R N-B 1$ and $V R N-D 1$. The wild type of the alleles of these genes is associated with a winter growth habit (recessive vrn$A 1, v r n-B 1$ and vrn-D1). Dominant alleles at these loci lead to a spring type growth habit (the transition to the generative phase in such plants occurs without exposure to low positive temperatures) and contain mutations in the promoter and/or the 1st intron relative to alleles of the wild type [33-36]. In regions with cold climates, including Western and Eastern Siberia, for spring wheat with dominant alleles associated with a spring habit (Vrn-A1a in combination with Vrn-B1a or Vrn-B1c), this combination allows the plant to complete its lifecycle after a relatively short vegetative period and escape autumn frosts [37-39]. For southern latitudes, varieties with one allele of Vrn-B1a or Vrn-D1a can have a definite advantage, as they ripen later, and a longer vegetative period can provide higher yields [37].

In general, spring wheat is a long-day plant. In addition to the VRN genes, the timing of heading in wheat is also determined by the allelic condition of the $P p d$ genes regulating the sensitivity of the plant to photoperiod. Furthermore, $P p d$ genes may be regulatory elements for other genes that are involved in light perception (PhyA, PhyB, PhyC) and flowering initiation (Vrn-1, TaFT1) [40-42]. According to their influence on the rate of plant development, these genes correlate with each other as follows: $P p d-D 1$ (strong influence) $>P p d-$ $B 1>P p d-A 1$ (weak influence) [43-46]. The dominant allele $P p d-D 1 a$ serves as the main source of insensitivity to photoperiod, which allows plants to flower at the optimal time in a short day. As a result, this allele is common in wheat in southern Europe, where it is exposed to short-day conditions [37, 47]. In regions with long daylight hours, this allele has no significant adaptive advantage and is extremely rare; the $P p d-D 1 b$ allele is most widespread in such regions [37, 38].

Variation in Rht, VRN, and Ppd genes can become a tool for the breeder to fine-tune the phenotype for specific agro-ecological conditions, including soil type, temperature, rainfall, and daylight hours. It is known that various allelic variants of $V r n$ and $P p d$ influence not only the duration of wheat phenophases and sensitivity to temperature and light conditions, but also the height of the plant and productivity elements [48-51]. Thus, combining different allelic variants of these genes is a way to develop wheat varieties that are best adapted to the local conditions in terms of straw height, the requirements of temperatures and daylight hours, and the ability to avoid adverse conditions during flowering, heading, ripening and harvesting of grain.

To ensure the economic stability of the Russian regions, it is necessary to develop their own agricultural production, especially wheat, which is supplied both to the domestic and foreign markets for baking, livestock feed, and for starch and alcohol production. The territory of Russia is characterized by a wide variety of agroclimatic conditions. Some regions are more suitable for cultivating winter wheat, others for spring wheat. Spring wheat occupies about half of the crop area under wheat in Russia, and one-third of gross wheat grain harvest. For specific agro-climatic conditions, it is important to choose the combination of straw height and the time of heading/flowering so that the plant can escape stressful conditions in the form of drought or frost, while giving the maximum possible crop of the best quality.

The aim of our work was to study the pleiotropic effect of the Rht-B1p allele (in comparison with Rht-B1a) on plant height and the main economically significant traits in interaction with the alleles of the vernalization genes $V R N-B 1$ and sensitivity to photoperiod $P p d-D 1$ in spring bread wheat. For field experiments, we selected two regions with contrasting conditions: Moscow and Krasnodar. These areas are characterized by contrasting agro-climatic conditions. The duration of the period with average daily temperatures above $10^{\circ} \mathrm{C}$ in Moscow does not exceed 138-140 days, while in the Krasnodar region it lasts for 180-187 days. The soils are sodpodzolic in Moscow and chernozems in Krasnodar. Despite the fact that both regions often receive sufficient and even excessive rainfall per year, the climate of these regions is characterized by sharp fluctuations and unpredictable droughts.

\section{Results}

The allelic state of Rht-B1, Rht-D1, Rht-8, Ppd-D1, VRN$A 1, V R N-B 1$, and $V R N-D 1$ was revealed via molecular 
analysis. The following genotypes were revealed for the parental plants: Chris Mutant: Rht-B1p Rht-B1p\crRhtD1a Rht-D1a \crRht-8a Rht-8a \crPpd-D1a PpdD1a \crVrn-A1a Vrn-A1a\crvrn-B1 vrn-B1 |crvrn-D1 vrn-D1; Novosibirskaya 67: Rht-B1a Rht-B1a \crRht-D1a Rht-D1a \crRht-8a Rht-8a \crPpd-D1b Ppd-D1b\crVrnA1a Vrn-A1a \crVrn-B1a Vrn-B1a\crvrn-D1 vrn-D1. Therefore, in the $F_{3: 4}$ families derived from the cross Chris Mutant/Novosibirskaya 67, segregation in the following three loci occured: Rht-B1 (Rht-B1a/Rht-B1p), Ppd-D1 (PpdD1a/PpdD1b) and VRN-B1 (Vrn-B1a/vrn$B 1)$. For convenience in describing results and comparing values of agronomic traits, we adopted the following abbreviations for the studied alleles:

Rht-B1a - R (tall plants, dominant allele).

Rht-B1p - r (semi-dwarf plants, recessive allele).

$V r n-B 1 a-\mathrm{V}$ (spring habit, dominant allele).

$v r n-B 1-\mathrm{v}$ (winter habit, recessive allele).

$P p d-D 1 a-P$ (photoperiod insensitive, dominant allele).

$P p d-D 1 b-\mathrm{p}$ (photoperiod sensitive, recessive allele).

The abbreviations for the genotypes used in the comparison and description of the revealed phenotypic effects are listed in Table 1.

\section{Plant height, internode length, and culm weight}

Both in Moscow and in Krasnodar, a significant difference in height was revealed between plants homozygous for the Rht-B1p dwarfing allele (semi-dwarf plants) and plants homozygous for the wild-type allele Rht-B1a (tall plants). Rht-B1p, compared to the wild-type allele, reduced the height by an average of $21 \mathrm{~cm}(28 \%)$ in Moscow, and by $25 \mathrm{~cm} \mathrm{(30 \% )} \mathrm{in} \mathrm{Krasnodar} \mathrm{(Add-}$ itional file 1 Table S1). At the same time, the difference in height between plants with the RRvv and rrvv genotypes was $25.5 \mathrm{~cm}(33 \%)$, and among families with the spring habit allele Vrn-B1a (RRVV and rrVV), was 19.9 $\mathrm{cm}(27 \%)$ in Moscow; and $28.5 \mathrm{~cm}(34 \%)$ and $25.2 \mathrm{~cm}$ (30\%) in Krasnodar, respectively. The two-way analysis of variance of the height between plants with differing sensitivity to photoperiod demonstrated that the

Table 1 The abbreviations for the genotypes in families $F_{3: 4}$ Chris Mutant/Novosibirskaya 67

\begin{tabular}{ll}
\hline Genotype & Abbreviations \\
\hline Rht-B1a Rht-B1a Vrn-A1a Vrn-A1a Vrn-B1a Vrn-B1a & RRW \\
Rht-B1a Rht-B1a Vrn-A1a Vrn-A1a vrn-B1 vrn-B1 & RRvv \\
Rht-B1p Rht-B1p Vrn-A1a Vrn-A1a Vrn-B1a Vrn-B1a & rrW \\
Rht-B1p Rht-B1p Vrn-A1a Vrn-A1a vrn-B1 vrn-B1 & rrvv \\
Rht-B1a Rht-B1a Ppd-D1a Ppd-D1a & RRPP \\
Rht-B1a Rht-B1a Ppd-D1b Ppd-D1b & RRpp \\
Rht-B1p Rht-B1p Ppd-D1a Ppd-D1a & rrPP \\
Rht-B1p Rht-B1p Ppd-D1b Ppd-D1b & rrpp \\
\hline
\end{tabular}

difference in height was $18.9 \mathrm{~cm}$ between RRpp and rrpp plants (25\%) and $19.9 \mathrm{~cm}$ between RRPP and rrPP plants (27\%) in Moscow; and $32.6 \mathrm{~cm}(38 \%)$ and $25.2 \mathrm{~cm}(30 \%)$ in Krasnodar, respectively (Table 2, Fig. 1).

The decrease in plant height as a whole was due to a significant reduction in the length of each individual internode; however, the length of the peduncle (first upper internode) was most strongly changed. In plants homozygous for the Rht-B1p allele, the peduncle was shorter by $10.6 \mathrm{~cm}$ (32\%) in Moscow and $12.1 \mathrm{~cm}(34 \%)$ in Krasnodar when compared to plants homozygous for $R h t-B 1 a$ grown under the same conditions (Table 2).

In our study, wheat plants had from four to five visible (elongated) internodes on the main stem; while in Moscow, five internodes were found in 37\% of tall plants (RR), and $20 \%$ of semi-dwarf plants (rr). The $7 \%$ variation in plant height in the experiment in Moscow could therefore be explained by the number of internodes. In Krasnodar, five internodes of the main stem accounted for $91 \%$ of tall plants (RR), and $63 \%$ of semi-dwarf plants (rr). The number of internodes explained $15 \%$ of the variability of the plant height in the experiment in Krasnodar.

The presence of the dominant allele of the Vrn-A1a gene in all the studied wheat plants means that they all have a spring habit. However, among them, there is segregation of the VRN-B1 gene, which theoretically can affect the rate of plant development and other agronomically important traits. In our study, families with and without the dominant allele Vrn-B1a (contributing to the spring habit), did not differ significantly from each other in plant height in either Moscow or Krasnodar (Additional file 1 Table S1).

Variation in alleles of the $P p d-D 1$ gene regulating plant response to day length had a small effect on plant height. In Moscow, Ppd-D1a demonstrated the tendency in plant height reduction, whilst in Krasnodar (short daylight hours) it slightly increased height (Additional file 1 Table S1). However, this difference in height did not play a major role in the field experiment. Two-way analysis of variance on the interaction between $R h t-B 1$ and $P p d-D 1$ in Moscow found no significant differences in height between plants. In Krasnodar, in the background of the dwarfing allele $R h t-B 1 p$, an increase in plant height under the action of an allele insensitive to daylength, $P p d-D 1 a$, was $6.3 \mathrm{~cm}(12 \%)$ (Table 2).

Semi-dwarf plant forms had a naturally smaller culm biomass. In plants carrying Rht-B1p, compared to plants with Rht-B1a, the biomass of the culm on average was $0.5 \mathrm{~g}$ less in both regions, which accounted for a 22 and $14 \%$ decrease in this trait in Moscow and Krasnodar, respectively. Statistically significant phenotypic differences in the culm biomass between plants with alternate $V R N$ B1 alleles were not revealed. In Moscow, Ppd-D1a 
Table 2 Mean values of biometric traits for main shoot in families $F_{3: 4}$ Chris Mutant/Novosibirskaya 67 grouped by Rht-B1 $\times$ VRN-B1 and Rht-B1 $\times$ Ppd-D1 alleles

\begin{tabular}{|c|c|c|c|c|c|c|}
\hline \multirow[t]{2}{*}{ Genotype } & \multicolumn{2}{|c|}{ Plant height, $\mathrm{cm}$} & \multicolumn{2}{|c|}{ Peduncle length, $\mathrm{cm}$} & \multicolumn{2}{|c|}{ Main shoot biomass, g } \\
\hline & Moscow & Krasnodar & Moscow & Krasnodar & Moscow & Krasnodar \\
\hline RRW & $73.4 \pm 1.5 \mathrm{a}^{\mathrm{a}}$ & $84.1 \pm 1.0 a$ & $32.9 \pm 1.1 a$ & $36 \pm 0.7 a$ & $2.3 \pm 0.1 a$ & $3.6 \pm 0.1 a$ \\
\hline RRvV & $77.2 \pm 3.3 a$ & $83.7 \pm 1.5 \mathrm{a}$ & $34.7 \pm 2 a$ & $36.6 \pm 1.6 a$ & $2.5 \pm 0.2 a$ & $3.7 \pm 0.2 \mathrm{a}$ \\
\hline $\mathrm{rrW}$ & $53.5 \pm 1.4 b$ & $58.9 \pm 1.2 b$ & $22.7 \pm 0.9 b$ & $24 \pm 0.5 b$ & $1.8 \pm 0.1 b$ & $3.1 \pm 0.3 b$ \\
\hline rrvv & $51.7 \pm 3.9 b$ & $55.1 \pm 6.4 b$ & $20.9 \pm 3.1 b$ & $23.2 \pm 4 b$ & $1.7 \pm 0.3 b$ & $2.4 \pm 0.9 a b$ \\
\hline RRPP & $73.4 \pm 1.5 \mathrm{a}$ & $84.1 \pm 1 a$ & $32.9 \pm 1.1 \mathrm{a}$ & $36 \pm 0.7 a$ & $2.3 \pm 0.1 a$ & $3.6 \pm 0.1 a$ \\
\hline RRpp & $74.9 \pm 1.8 \mathrm{a}$ & $85.2 \pm 1.2 \mathrm{a}$ & $33.5 \pm 1.3 a$ & $35.3 \pm 0.8 a$ & $2.4 \pm 0.1 \mathrm{a}$ & $3.8 \pm 0.2 \mathrm{a}$ \\
\hline $\operatorname{rrPP}$ & $53.5 \pm 1.4 b$ & $58.9 \pm 1.2 b$ & $22.7 \pm 0.9 b$ & $24 \pm 0.5 b$ & $1.8 \pm 0.1 b$ & $3.1 \pm 0.3 b$ \\
\hline rrpp & $56 \pm 2.6 b$ & $52.6 \pm 1.2 c$ & $24.6 \pm 1.5 b$ & $21.3 \pm 0.8 c$ & $1.9 \pm 0.2 b$ & $2.9 \pm 0.3 b$ \\
\hline
\end{tabular}

Mean value \pm confidence intervals at 0.01 significance level are shown

${ }^{a}$ Mean values designated with the same letters have no significant differences within each group of four genotypes (RRVV, RRvv, rrVV, rrvv and RRPP, RRpp, rrPP, rrpp) as calculated using two-way ANOVA

reduced the culm biomass by $0.2 \mathrm{~g}$; however, this effect was not observed after considering particular differences in the two-way analysis of Rht-B1/Ppd-D1 (Table 2, Additional file 1 Tables S1).

\section{Structure and productivity of the spike}

In a one-way analysis, plants with the Rht-B1p dwarfing allele had a shorter and more compact spike compared to tall plants. While plants with the allele of photoperiodic insensitivity, Ppd-D1a, had less spike compactness than plants with a genotype sensitive to photoperiod. The relationship between the length and spike compactness and the alleles of the VRN-B1 gene as a whole does not show a single trend, but rather depends on the growing region and genotype for the $R h t-B 1$ gene. The strongest influence on spike compactness among the studied genes in Moscow came from Rht-B1, while in
Krasnodar it was the $P p d-D 1$ gene (Additional file 1 Table S5).

Semi-dwarf plants had, on average, lower main spike productivity (grain weight per main spike) both in Moscow (by $0.24 \mathrm{~g}, 20 \%$ ) and in Krasnodar (by $0.09 \mathrm{~g}$, $6 \%$ ) compared to tall plants. Only in the conditions of a short day in the Krasnodar Krai, the allele of photoperiodic insensitivity $P p d-D 1 a$ contributed to mitigation of the negative effect of $R h t-B 1 p$ on spike productivity (Additional file 1 Table S2). In Krasnodar, in plant families with the photoperiod insensitive allele $P p d-D 1 a$, the decrease in spike productivity associated with $R h t-B 1 p$ was $6 \%(0.08 \mathrm{~g})$, and in the absence of Ppd-D1a, it was $15 \%$ (0.21 g). In Moscow conditions, Ppd-D1a had no effect on spike productivity. Plants differing in alleles of the $V R N-B 1$ gene did not differ significantly in spike productivity (Table 3 ).

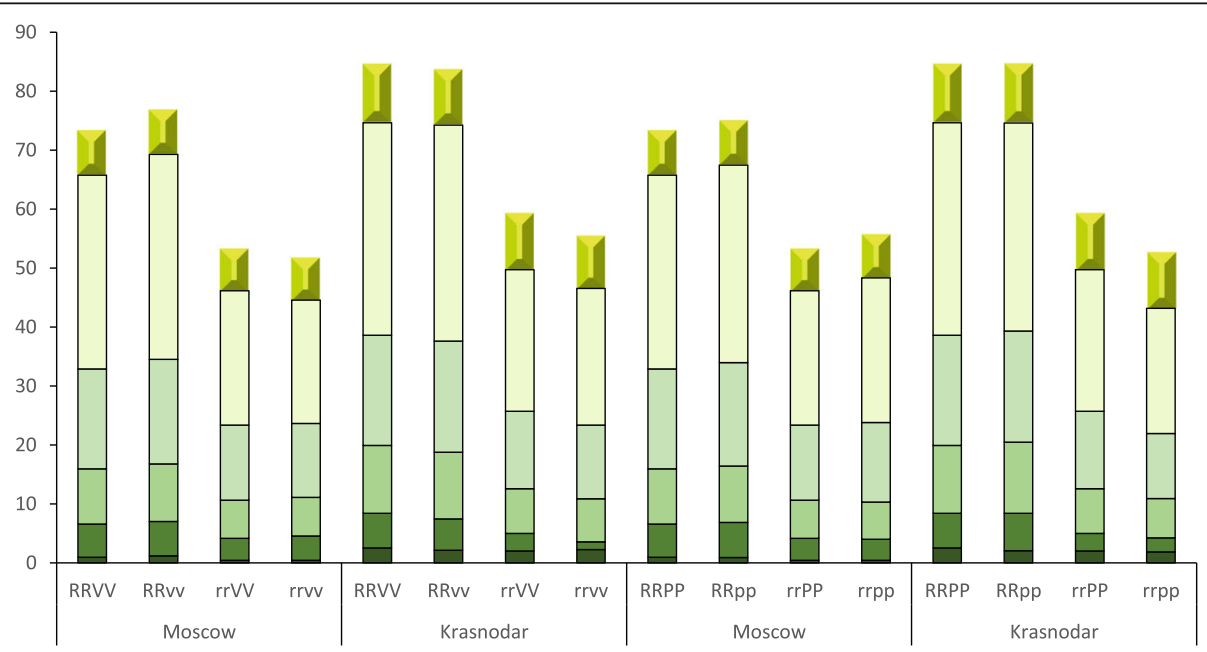

Fig. 1 Mean length of spike and internodes in the families $F_{2: 4}$ derived from the cross Chris Mutant/Novosibirskaya $67: R-R h t-B 1 a, r-R h t-B 1 p ; V$ - Vrn-B1a, v - vrn-B1; P - Ppd-D1a, p - Ppd-D1b. The 4th upper internode is not depicted. Total plant height differs from the mean plant height in Table 4 due to polymorphism in the number of internodes between plants 
Table 3 Mean values of biometric traits of spike productivity traits in families $F_{3: 4}$ Chris Mutant/Novosibirskaya 67 grouped by Rht$B 1 \times V R N-B 1$ and $R h t-B 1 \times P p d-D 1$ alleles

\begin{tabular}{|c|c|c|c|c|c|c|}
\hline \multirow[t]{2}{*}{ Genotype } & \multicolumn{2}{|c|}{ Grain weight in main spike, $g$} & \multicolumn{2}{|c|}{ Grain number per main spike, pcs. } & \multicolumn{2}{|c|}{ Thousand grain weight, $\mathrm{g}$} \\
\hline & Moscow & Krasnodar & Moscow & Krasnodar & Moscow & Krasnodar \\
\hline$\overline{R R W}$ & $1.17 \pm 0.1 a^{a}$ & $1.43 \pm 0.1 \mathrm{a}$ & $35.2 \pm 1.3 a b$ & $48.5 \pm 1.5 \mathrm{a}$ & $32.9 \pm 0.7 a$ & $29.5 \pm 0.8 a$ \\
\hline RRvv & $1.25 \pm 0.1 a$ & $1.51 \pm 0.1 \mathrm{a}$ & $37.7 \pm 3 a$ & $48.6 \pm 3.9 a$ & $32.8 \pm 1.9 a$ & $31.4 \pm 1.8 \mathrm{a}$ \\
\hline $\mathrm{rrW}$ & $0.95 \pm 0.1 b$ & $1.35 \pm 0.1 b$ & $33.6 \pm 1.5 b$ & $50.2 \pm 1.4 a$ & $27.6 \pm 0.8 b$ & $27 \pm 0.7 b$ \\
\hline rrvv & $0.9 \pm 0.2 b$ & $1.07 \pm 0.5 b$ & $31.4 \pm 4.8 b$ & $42.6 \pm 14 a$ & $28.3 \pm 1.7 b$ & $24.8 \pm 5.2 b$ \\
\hline RRPP & $1.17 \pm 0.1 \mathrm{a}$ & $1.43 \pm 0.1 a$ & $35.2 \pm 1.3 b c$ & $48.5 \pm 1.5 \mathrm{a}$ & $32.9 \pm 0.7 a$ & $29.5 \pm 0.8 a$ \\
\hline RRpp & $1.24 \pm 0.1 a$ & $1.41 \pm 0.1 \mathrm{ab}$ & $38.1 \pm 1.7 \mathrm{a}$ & $49.5 \pm 1.7 a$ & $32.1 \pm 1.1 a$ & $28.5 \pm 0.8 a$ \\
\hline $\operatorname{rrPP}$ & $0.95 \pm 0.1 b$ & $1.35 \pm 0.1 b$ & $33.6 \pm 1.5 c$ & $50.2 \pm 1.4 a$ & $27.6 \pm 0.8 b$ & $27 \pm 0.7 b$ \\
\hline $\operatorname{rrpp}$ & $1.01 \pm 0.1 b$ & $1.2 \pm 0.2 c$ & $37.5 \pm 3.2 \mathrm{ab}$ & $47.6 \pm 3.7 \mathrm{a}$ & $26.2 \pm 1.3 b$ & $24.8 \pm 2 c$ \\
\hline
\end{tabular}

Mean value \pm confidence intervals at 0.01 significance level are shown

${ }^{a}$ Mean values designated with the same letters have no significant differences within each group of four genotypes (RRVV, RRvv, rrVV, rrvv and RRPP, RRpp, rrPP, rrpp) as calculated using two-way ANOVA

The productivity of the ear depends on the number of grains and the average weight of 1000 grains. In Krasnodar, plants with different allelic states of the studied genes Rht-B1, Ppd-D1, and VRN-B1 did not differ significantly in the grain number per spike. In Moscow, allele $P p d-D 1$ a reduced the grain number per spike by 3-4 grains (9\%) (Additional file 1 Table S2). On average, plants carrying Vrn-B1a and vrn-B1 did not significantly differ in the grain number per spikelet, however, the presence of the dominant allele Vrn-B1a mitigated the contrast between short and tall plants, generating a 5\% reduction (1-2 kernels) in RRVV vs rrVV (plants with Vrn-B1a) compared with a $17 \%$ reduction (6 grains) in RRvv vs rrvv (plants with vrn-B1). The influence of the studied alleles on the 1000 grain weight is similar to the abovedescribed influence on the productivity of the spike as a whole. In Moscow, Rht-B1p significantly and independently of the allelic condition of the VRN-B1 and $P p d-D 1$ genes, reduces this productivity by $16-$ $18 \%$. But in Krasnodar, the presence of the Ppd-D1a allele tended towards mitigation of the negative effect of Rht-B1p. Therefore, the dwarfing allele Rht-B1p in the absence of the allele Ppd-D1a led to a decrease in 1000 grain weight by $13 \%$ (RRpp and rrpp), but in the presence of the allele Ppd-D1a, $8 \%$ only (RRPP and rrPP) (Table 3).

Thus, the alleles insensitive to photoperiod $P p d-D 1 a$ and $R h t-B 1 p$, showed in our experiments the opposite effect on 1000 grain weight and grain weight per spike, which allows us to consider Ppd-D1a as a compensator for the negative effect of $R h t-B 1 p$ on plant productivity under the conditions of Krasnodar. Moreover, both alleles, Rht-B1p and Ppd-D1a, showed a tendency to increase the harvest index compared to wild-type alleles Rht-B1a and Ppd-D1b (Additional file 1 Table S3).

\section{Heading, the sum of effective temperatures and daylight} hours

In Moscow, heading time in semi-dwarf plant families (rr) came slightly later than in tall families (RR) among plants with Vrn-B1a. Also, semi-dwarf plants (rr) in families with the $V r n-B 1 a$ allele required a higher sum of active temperatures $\left(>10^{\circ} \mathrm{C}\right)$ and active light days $(>12 \mathrm{~h}$ ) for heading of 5 and $3 \%$, respectively, compared to the tall plants (RR). Under the climatic conditions of Krasnodar, no differences were found between families homozygous for the alleles of the Rht-B1 and VRN-B1 genes (Table 4).

In Moscow, the two-way analysis of the interaction of Rht-B1 and Ppd-D1 showed that heading in semidwarf plants (rr) came a little later compared to tall plants (RR) in families with photoperiod sensitivity allele $P p d-D 1 b$ and photoperiod insensitivity allele $P p d$ D1a. The sum of active temperatures and daylight hours are higher for semi-dwarf plants ( $\mathrm{rr}$ ) than tall plants (RR) by an average of 4 and 3\%. Tall plants carrying the allele of insensitivity Ppd-D1a (RRPP) headed a bit earlier than those with the photoperiod sensitive allele (RRpp), and their demand for the sum of active temperatures and light days decreased by 3 and $2 \%$, respectively (Table 4 ).

Under the conditions of Krasnodar, we identified a significant difference in heading time between plants homozygous for different alleles of $P p d-D 1$. Families with the $P p d-D 1 a$ insensitivity allele were earlier than those with the $P p d-D 1 b$ sensitivity allele, the difference was 7 days among tall plants (RRPP and RRpp), and 5 days among semi-dwarf plants (rrPP and rrpp). Additionally, in the presence of the photoperiod-insensitive allele, $P p d-D 1 a$, the demand for active temperatures and light days decreased by an average of 13 and $10 \%$, respectively (Table 4 , Additional file 1 Table S4). 
Table 4 Mean values of heading date, sum of active $\left(>10^{\circ} \mathrm{C}\right)$ temperatures and active $(>12 \mathrm{~h})$ light days from sowing to heading date in families $\mathrm{F}_{3: 4}$ Chris Mutant/Novosibirskaya 67 grouped by Rht-B1 $\times$ VRN-B1 and Rht-B1 $\times$ Ppd-D1 alleles

\begin{tabular}{|c|c|c|c|c|c|c|}
\hline \multirow[t]{2}{*}{ Genotype } & \multicolumn{2}{|c|}{ Heading date, days from sowing to heading } & \multicolumn{2}{|c|}{$\begin{array}{l}\text { Sum of active }\left(>10^{\circ} \mathrm{C}\right) \text { temperatures to } \\
\text { heading date, }{ }^{\circ} \mathrm{C}\end{array}$} & \multicolumn{2}{|c|}{$\begin{array}{l}\text { Sum of active ( }>12 \mathrm{~h} \text { ) light days to } \\
\text { heading date, } \mathrm{h}\end{array}$} \\
\hline & Moscow & Krasnodar & Moscow & Krasnodar & Moscow & Krasnodar \\
\hline RRW & $52.7 \pm 0.7 b^{a}$ & $65 \pm 2.3 a$ & $810 \pm 15 b$ & $861 \pm 48 a$ & $875 \pm 12 b$ & $883 \pm 35 a$ \\
\hline RRvv & $53.5 \pm 1.4 a b$ & $62.3 \pm 6 a$ & $828 \pm 30 a b$ & $802 \pm 132 a$ & $890 \pm 24 a b$ & $841 \pm 90 a$ \\
\hline $\mathrm{rrW}$ & $54.4 \pm 1 a$ & $64.6 \pm 1.3 a$ & $847 \pm 21 a$ & $854 \pm 28 a$ & $906 \pm 18 a$ & $877 \pm 20 a$ \\
\hline rrvv & $54.2 \pm 2 a b$ & $66 \pm 4.1 \mathrm{a}$ & $842 \pm 44 a b$ & $884 \pm 104 a$ & $901 \pm 35 a b$ & $898 \pm 80 a$ \\
\hline RRPP & $52.7 \pm 0.7 c$ & $65 \pm 2.3 b$ & $810 \pm 15 c$ & $861 \pm 48 b$ & $875 \pm 12 c$ & $883 \pm 35 b$ \\
\hline RRpp & $53.7 \pm 0.8 \mathrm{bc}$ & $71.9 \pm 3.7 \mathrm{a}$ & $831 \pm 17 b c$ & $1003 \pm 76 a$ & $893 \pm 14 b c$ & $988 \pm 56 a$ \\
\hline $\operatorname{rrPP}$ & $54.4 \pm 1 a b$ & $64.6 \pm 1.3 b$ & $847 \pm 21 a b$ & $854 \pm 28 b$ & $906 \pm 18 a b$ & $877 \pm 20 b$ \\
\hline rrpp & $55.1 \pm 1.2 \mathrm{a}$ & $70 \pm 5.2 a$ & $861 \pm 25 a$ & $967 \pm 104 a$ & $917 \pm 20 a$ & $959 \pm 80 a$ \\
\hline
\end{tabular}

Mean value \pm confidence intervals at 0.01 significance level are shown

${ }^{a}$ Mean values designated with the same letters have no significant differences within each group of four genotypes (RRVV, RRvv, rrVV, rrvv and RRPP, RRpp, rrPP, rrpp) as calculated using two-way ANOVA

\section{Gene interaction analysis}

To identify the most significant relationships between the allelic condition of the studied genes, we conducted a pairwise regression analysis for each pair of genes: $R h t$ $B 1$ and $V R N-B 1, R h t-B 1$ and $P p d-D 1$, for each region of the field experiment. Correlation coefficients for $R h t-B 1$ in both pairs of comparison coincided, or were very close, within each region of the field experiment, so we demonstrate here the average value of correlation coefficients (Table 5).
In Moscow, a strong negative correlation was shown between the presence of $R h t-B 1 p$ in the genotype and plant height (explaining $50 \%$ of the variability). There was a moderate negative correlation between the presence of $R h t-B 1 p$ and main culm weight, length of first internode, 1000 grain weight (20\% of the variability), vegetative part of the main shoot, and grain weight of the main spike ( $8 \%$ of the variability). A moderate positive correlation was found between the presence of $R h t$ $B 1 p$ and the requirements for the sum of active

Table 5 Correlation coefficients between the presence of the Rht-B1p, Vrn-B1a, and Ppd-D1a alleles in homozygotes and valuable agronomic traits in families $\mathrm{F}_{3: 4}$ Chris Mutant/Novosibirskaya 67

\begin{tabular}{|c|c|c|c|c|c|c|}
\hline \multirow[t]{2}{*}{ Agronomic trait } & \multicolumn{2}{|l|}{ Rht-B1p } & \multicolumn{2}{|l|}{ Vrn-Bla } & \multicolumn{2}{|l|}{ Ppd-D1a } \\
\hline & Moscow & Krasnodar & Moscow & Krasnodar & Moscow & Krasnodar \\
\hline Plant height $(\mathrm{PH})$ & $-0.71^{a}$ & $-0.90^{\mathrm{a}}$ & -0.03 & 0.02 & $-0.06^{a}$ & $0.04^{a}$ \\
\hline Internode number (IN) & $-0.13^{a}$ & $-0.27^{a}$ & -0.05 & 0.02 & 0.03 & $-0.15^{a}$ \\
\hline Peduncle length (PL) & $-0.59^{a}$ & $-0.86^{\mathrm{a}}$ & -0.01 & -0.01 & $-0.06^{\mathrm{a}}$ & $0.09^{a}$ \\
\hline Main spike length (MSL) & $-0.15^{a}$ & $-0.11^{\mathrm{a}}$ & -0.01 & $0.14^{\mathrm{a}}$ & -0.02 & -0.01 \\
\hline Spikelet number per main spike (SN) & 0.003 & -0.05 & -0.04 & -0.02 & $-0.15^{\mathrm{a}}$ & $-0.26^{a}$ \\
\hline Spike compactness (SC) & $0.16^{\mathrm{a}}$ & $0.06^{\mathrm{a}}$ & -0.03 & $-0.15^{\mathrm{a}}$ & $-0.13^{\mathrm{a}}$ & $-0.23^{a}$ \\
\hline Main spike weight (MSW) & $-0.29^{a}$ & $-0.11^{\mathrm{a}}$ & -0.04 & -0.01 & $-0.09^{a}$ & 0.04 \\
\hline Main culm weight (MCW) & $-0.54^{a}$ & $-0.19^{a}$ & $-0.08^{\mathrm{a}}$ & 0.004 & $-0.10^{a}$ & -0.04 \\
\hline Main shoot biomass (MSB) & $-0.40^{\mathrm{a}}$ & $-0.21^{a}$ & -0.05 & 0.00 & $-0.10^{a}$ & -0.02 \\
\hline Grain weight per main spike (GW) & $-0.29^{a}$ & $-0.15^{\mathrm{a}}$ & -0.02 & -0.01 & $-0.08^{a}$ & $0.08^{a}$ \\
\hline Grain number per main spike (GN) & $-0.09^{a}$ & 0.06 & -0.02 & 0.04 & $-0.16^{a}$ & 0.01 \\
\hline Grain number per spikelet (GNS) & $-0.11^{\mathrm{a}}$ & 0.09 & 0.01 & 0.05 & $-0.09^{\mathrm{a}}$ & $0.16^{a}$ \\
\hline Thousand grain weight, g (W) & $-0.45^{a}$ & $-0.29^{a}$ & -0.01 & -0.07 & $0.08^{a}$ & $0.14^{\mathrm{a}}$ \\
\hline Harvest index (HI) & $0.12^{\mathrm{a}}$ & 0.07 & 0.05 & 0.02 & 0.02 & $0.10^{a}$ \\
\hline Heading date $(H)$ & $0.47^{\mathrm{a}}$ & $-0.06^{\mathrm{a}}$ & -0.06 & $0.19^{a}$ & $-0.35^{\mathrm{a}}$ & $-0.63^{\mathrm{a}}$ \\
\hline Sum of active $\left(>10^{\circ} \mathrm{C}\right)$ temperatures to heading date, ${ }^{\circ} \mathrm{C}(\mathrm{SAT})$ & $0.47^{\mathrm{a}}$ & $-0.05^{\mathrm{a}}$ & -0.06 & $0.19^{a}$ & $-0.36^{\mathrm{a}}$ & $-0.63^{a}$ \\
\hline Sum of active (> $12 \mathrm{~h}$ ) light days to heading date, $\mathrm{h}$ (SAD) & $0.47^{a}$ & $-0.06^{a}$ & -0.06 & $0.19^{a}$ & $-0.35^{a}$ & $-0.64^{a}$ \\
\hline
\end{tabular}

${ }^{a}$ correlations significant at the 0.05 significance level 
temperatures and active daylight hours, as well as heading date ( $20 \%$ of the variability). For $P p d-D 1 a$, a moderate negative correlation with the requirements for the sum of active temperatures, active daylight hours, and heading date $(12 \%$ of the variability) were revealed (Table 5, Fig. 2).

In Krasnodar, a strong negative correlation was shown between the presence of the Rht-B1p in the plant genotype and plant height (explaining $81 \%$ of the variability) and the peduncle length; a moderate negative correlation was recorded between the presence of $R h t-B 1 p$ and 1000 grain weight ( $9 \%$ of the variability), and the number of internodes. Moderate negative correlations between the presence of $P p d-D 1 a$ and the requirements for the sum of active temperatures, active daylight hours, and heading date ( $40 \%$ of the variability) and the number of spikelets (40\% of the variability) were also revealed (Table 5, Fig. 2).

Thus, both in Moscow and Krasnodar, aside from the reduction in plant height, Rht-B1p showed a negative impact on the 1000 grain weight. The association between the presence of $R h t-B 1 p$ and the grain weight per main spike was moderate in Moscow and weak in
Krasnodar. The association between the presence of $R h t$ $B 1 p$ and the grain number per main spike was weak in both regions of the field experiment. Thus, in Krasnodar the selection for plants of spring wheat that carry Rht$B 1 p$, with a slight decrease of 1000 grain weight and grain number per main spike is more likely, as the correlation between the presence of $R h t-B 1 p$ and these characteristics is weak (Table 5, Fig. 2).

The Principal Component Analysis (PCA) performed for Rht-B1p and Vrn-B1a demonstrated the following tendencies (Fig. 3a and c). The Rht-B1p and plant height $(\mathrm{PH})$ vectors are directed opposite to each other; "RR" families (empty and filled circles) are located near the $\mathrm{PH}$ vector (plant height), which generally describes them as tall plants. Conversely, "rr" families (half-circles and a dot) are in the opposite direction, close to the $R h t-B 1 p$ vector. As can be seen in the biplot in Fig. 3a (Moscow), the circles that are most productive (i.e. close to vectors GW, GN, W) are dark circles (RRvv) and with a dot (rrvv), that is, plants with the recessive vrn-B1 allele. At the same time, in the biplot for Krasnodar, no tendencies can be observed for the distribution of the circles in relation to the vectors of the productivity elements

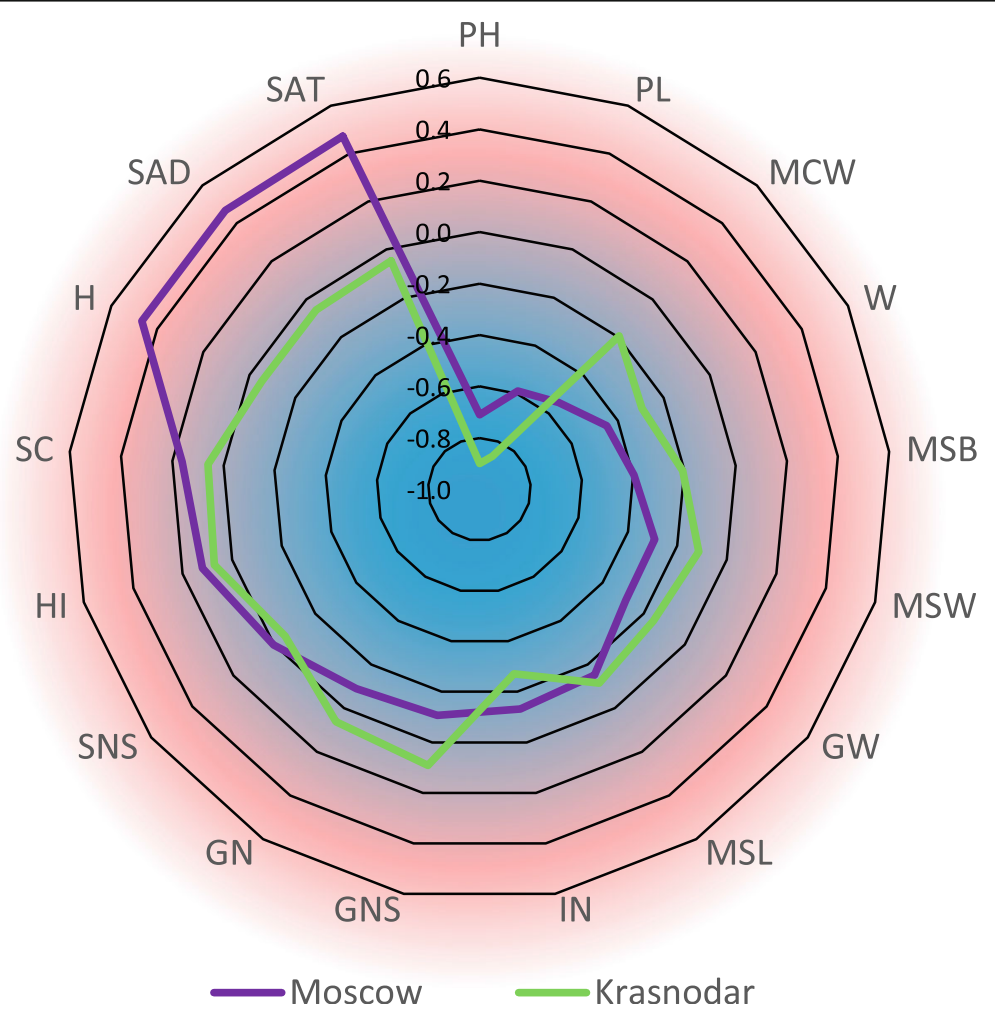

Fig. 2 Correlation coefficients between the presence of the Rht-B1p, Vrn-B1a, and Ppd-D1a alleles in homozygotes and valuable agronomic traits in families $F_{3: 4}$ Chris Mutant/Novosibirskaya 67 in field tests in Moscow (violet line) and Krasnodar (green line). Blue and red represent negative and positive correlations respectively. PH, plant height; IN, internode number; PL, peduncle length; MSL, main spike length; SN, spikelet number; SC, spike compactness; MSW, main spike weight; MCW, main culm weight; MSB, main shoot biomass; GW, grain weight per main spike; GN, grain number per main spike; GNS, grain number per spikelet; $W$, thousand grain weight; $H I$, harvest index; $H$, heading date; SAT, sum of active $\left(>10^{\circ} \mathrm{C}\right)$ temperatures to heading date; SAD, sum of active (> $12 \mathrm{~h}$ ) light days to heading date 

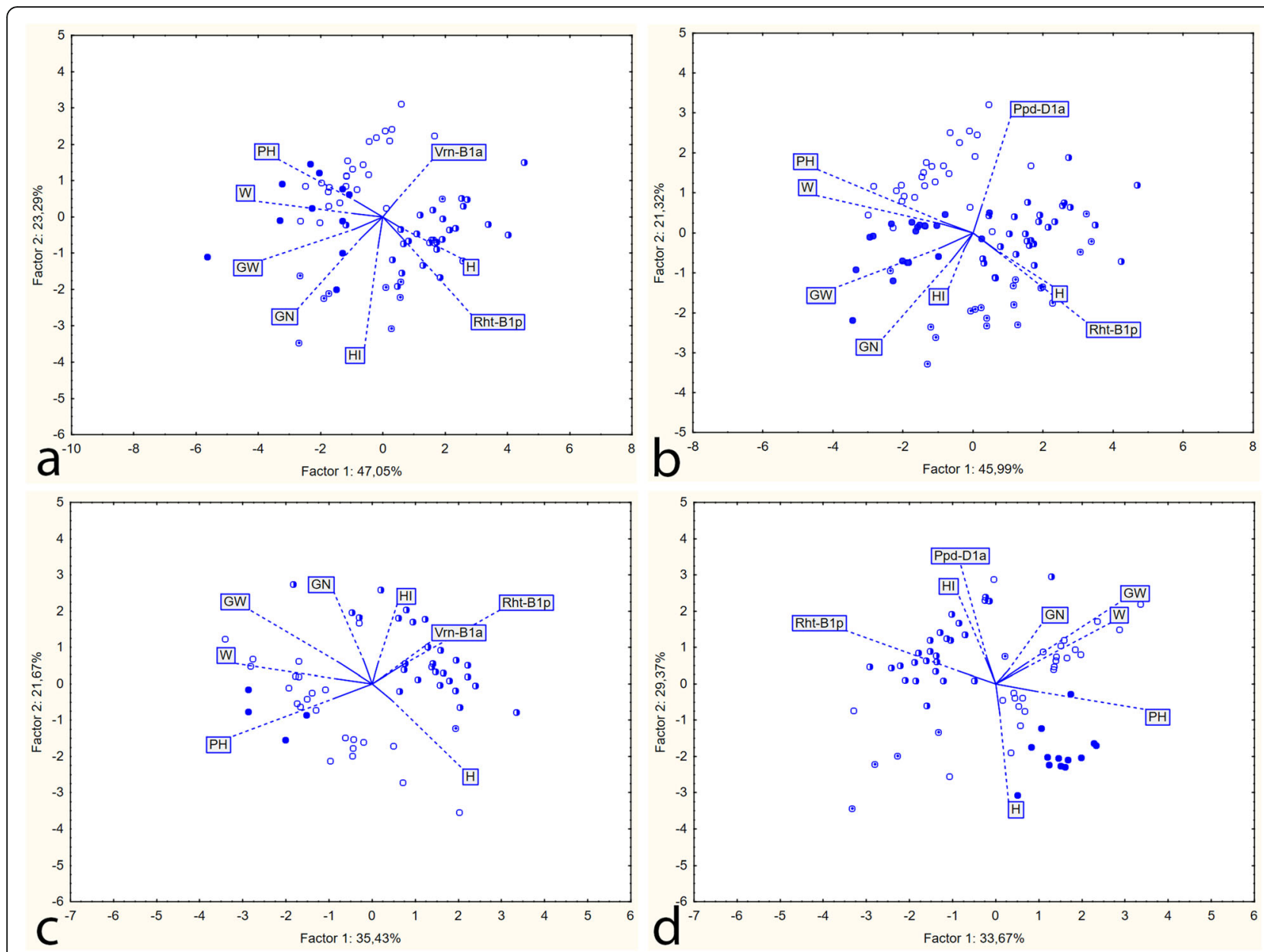

Fig. 3 Principal Components Analysis Biplot: a) interaction between Rht-B1p and Vrn-B1a, Moscow; b) interaction between Rht-B1p and Ppd-D1a, Moscow; C) interaction between Rht-B1p and Vrn-B1a, Krasnodar; d) interaction between Rht-B1p and Ppd-Dla, Krasnodar. Depiction of genotypes

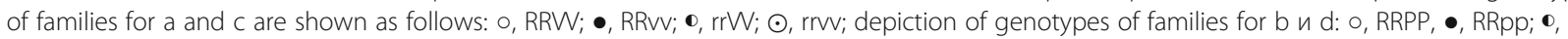
rrPP, $\odot$, rrpp. Vectors are shown in full lines; dashed lines are used for the labels

(Fig. 3c). In addition, no patterns for scattering with respect to the heading date vector $(\mathrm{H})$ were detected for the groups of genotypes. Thus, selection for productive semi-dwarf plants in Moscow is more achievable among plants with $V r n-A 1 / v r n-B 1$ alleles, and in Krasnodar among those with both variants of the Vrn-A1/vrn-B1 and $V r n-A 1 / V r n-B 1 a$ alleles.

The PCA analysis of the interaction between $R h t-B 1 p$ and the photoperiod-insensitive allele $P p d-D 1 b$ demonstrated the following trends (Fig. $3 \mathrm{~b}$ and d): Rht-B1p and plant height $(\mathrm{PH})$ vectors are directed opposite to each other; "RR" families (empty and filled circles) are located near the $\mathrm{PH}$ vector (plant height), which generally describes them as tall plants. Conversely, "rr" families (half circles and with a dot) are located in the opposite direction, close to the Rht-B1p vector. As can be seen in the biplot in Fig. 3b, the most productive (i.e. close to vectors GW, GN, W) are dark circles (RRpp) and with rrpp; that is, plants with the sensitivity allele $P p d-D 1 b$.
However, in the biplot in Fig. 3d (Krasnodar), the most productive families are represented by empty (RRPP) and a half (rrPP) circles; that is, plants with insensitivity $P p d-D 1 a$. Thus, it is more likely to select for more productive semi-dwarf plants among the families with the photoperiod-sensitive allele $P p d-D 1 b$ in Moscow, and with the photoperiod-insensitive allele Ppd-D1a in Krasnodar.

\section{Discussion}

The application of new dwarfing alleles in wheat breeding in combination with the alleles of vernalization and photoperiod sensitivity allows for an expansion in the adaptability of this crop to various cultivation conditions. The yield of wheat is to higher extent is determined by the combination of the allelic variants of $R h t$, $V r n$ and Ppd reffered to as "core genes" or "adaptaion genes" by some authors [52, 53]. In our research, we evaluated the phenotype of the new dwarfing allele $R h t$ - 
$B 1 p$ in spring bread wheat in combination with the alleles of vernalization gene $V R N-B 1$ and the photoperiodsensitive gene $P p d-D 1$ in two regions, Moscow and Krasnodar, which differ in the length of daylight and soil and climatic conditions. In our study, the variation in valuable agronomic traits in semi-dwarf plants bearing the $R h t-B 1 p$ allele associated with the phenotypic manifestation of the Ppd-D1a and Ppd-D1b alleles was more diverse than that associated with the Vrn-B1a and vrn-B1 alleles. The stronger phenotypic effects of $P p d-D 1$ in Krasnodar can be explained by the short daylight conditions in which the effect of the photoperiod-insensitive gene becomes evident. Under the conditions of a long day in Moscow, the influence of the allelic condition of this gene is not noticeable.

Among the GA-insensitive dwarfing alleles of Rht-B1, the most common allele is Rht-B1b. The effect of $R h t$ $B 1 b$ on plant height is well studied and varies in the range of $10-25 \%[14,15,27,54,55]$. In our studies, the difference in height between plants with the allele $R h t$ $B 1 p$ and Rht-B1a ranged between 27 and $34 \%$. This difference in height between Rht-B1p and Rht-B1a homozygous plants was similar to that obsreved in segragating population in the same cross in a $F_{2}$ vegetative experiment [7], as well as when comparing mutant forms of the Mutant Chris, donor of Rht-B1p (previously designted as Rht17), with the original wheat variety Chris [19]. Noteworthy, the phenotypic effect of Rht-B1p on plant height is comparable to Rht-B1e. Analysis of the nucleotide sequences of the alleles showed that stop codons caused by point mutations are found nearby in Rht-B1e and Rht-B1p [7], which may be the probable reason for the close phenotypic manifestation of these alleles. The Rht-B1e allele was detected in $16.5 \%$ of accessions from the collection from southern Russia [8]. $R h t-B 1 p$ can be used in breeding in conjunction with $R h t-B 1 e$, after replacing the negative genetic background of the Chris Mutant.

In our experiments, the Ppd-D1a allele in Moscow did not have a statistically significant effect on plant height, although we did note a tendency toward reduced plant height in the experiment in Moscow by $2-5 \%$. In a field experiment in Krasnodar, semi-dwarf plants carrying Rht-B1p with the allele $P p d-D 1 a$ were significantly taller than those with allele Ppd-D1b by $12 \%$; that is, the photoperiod-insensitive allele had an effect opposite to the height-reducing effect of Rht-B1p. Li et al. (2013) showed that the Rht-B1h allele reduced plant height only in plants with the Ppd-D1a allele [2]. According to the published data, $P p d-D 1 a$ reduces height in the range of $4-15 \%[9,17,49-51,56]$. There is an assumption that the effect of $P p d-D 1 a$ is due to its linkage to the $R h t-8 c$ dwarfing allele, since this allele also leads to photoperiod insensitivity and to accelerated flowering and heading
[50]. However, we have shown that both parent forms carry the wild-type allele $R h t-8 a$, which when present in the genome leads to a tall plant phenotype. Therefore, in our opinion, the difference in height under the influence of this allele Ppd-D1a, is first of all due to the change in the duration of the vegetative phase, which in turn leads to a change in the habit of the plant.

In our studies in both regions of the field experiment, weak negative correlation between spikelet number per spike and the presence of photoperiod-insensitive allele $P p d-D 1 a$ in plants and was observed. This tendency agrees with many previous studies $[43,50,51]$.

In our studies in Moscow, Rht-B1p on average negatively affected grain number per main spike due to a decrease in grain number per spikelet. Moreover, this trait was also influenced by the interaction with the VRN-B1 gene. In Krasnodar, there was a tendency to an increase in grain number per spike due to an increase in grain number per spikelet and spikelet number per main spike in plants with $R h t-B 1 p$, but only in the genetic background of Ppd-D1a and Vrn-B1a. This suggests a multidirectional interaction between the alleles of $P p d-D 1$, $R h t-B 1$ and $V R N-B 1$ genes, depending on the region of the experiment.

In our field experiment in Moscow, a negative influence of the photoperiod-insensitive allele Ppd-D1a on the grain number per spike was shown (a decrease of 8 $11 \%$, a weak but significant negative correlation). While in Krasnodar, in contrast, grain number per spike was greater in semi-dwarf plants with Ppd-D1a. Many studies show that $P p d-D 1$ affects 1000-grain weight, vegetative weight, harvest index and grain yield [57, 58]. Alleles of photoperiod sensitivity have both negatively and positively influenced grain number per spike, as well as the percentage of fertile flowers in different experiments [50, 51, 59].

Under the influence of Rht-B1p, 1000 grain weight decreased, which is especially noticeable in the PCA biplots where the Rht-B1p and 1000 grain weight vectors have opposite directions (Fig. 3). In our experiments, 1000 grain weight decreased under the influence of Rht-B1p by $14-18 \%$ in Moscow and by $9-21 \%$ in Krasnodar when different groups of genotypes were compared. A number of studies have shown that Rht-B1b reduces 1000 grain weight (or the weight of individual grains), although in a number of experiments the effect was not statistically significant $[14,15,27,55,60]$. With a decrease in plant height, the availability of assimilates to the upper flowers in the spikelet increases, whereas in tall plants, as a rule, they do not produce grain. As a result, the number of grains in the ear increases. There is also another side: this leads to a decrease in 1000 grain weight, the grain becomes smaller due to increasing competition for assimilates. In addition, this may be 
because the straw itself as a source of the organic matter becomes shorter, generating a deficit for grain filling.

We found that $V r n-B 1 a$ tends to mitigate the negative effect of $R h t-B 1 p$ on grain number per spike in both regions and 1000 grain weight in Krasnodar. We also demonstrated in the experiments in both regions that PpdDla can partially compensate for the negative effect of Rht-B1p on 1000 grain weight, for 4-9\% in Krasnodar and for $2-5 \%$ in Moscow, that is in agrrement with literature $[50,51,61]$.

In Moscow and Krasnodar, grain weight per main spike from plants homozygous for $R h t-B 1 p$ was lower compared to that of plants homozygous for Rht-B1a. The influence of dwarfing on the productivity of plants or spike depends on a large number of multidirectional factors. In the studies by Chen et al. [50, 51], the maximum grain yield per plant was observed in genotypes of tall plants, although semi-dwarf plants with a combination of a GA-sensitive gene Rht-5 and photoperiodinsensitive alleles had the same yield as that of tall plants [50]. It should be considered that despite the higher potential yield from tall plants, this is not always achievable, especially with intensive cultivation technology where the risk of lodging is high.

Flowering time is the key factor in the adaptation of plants to various environmental conditions and is critical for avoiding the risks of drought, frost or heat during the reproductive period of development. GA-insensitive short-stem alleles generally do not affect flowering time themselves $[12,15]$. Neverthelss, some authors observe some effect of Rht-B1 region on earliness that might be associated with putative genes located in the vicinity of $R h t-B 1$ [52, 62]. Later flowering / heading is observed in plants with GA-sensitive dwarfing genes [50, 51, 63]. $P p d-D 1$ had a much greater effect in Krasnodar, where $P p d-D 1 a$ accelerated heading by $5-7$ days. It is known from the literature that $P p d-D 1 a$ accelerates flowering on short days $[9,50,64,65]$, which was also observed in our experiments.

Dwarfing alleles reduce the stem height and thereby allow the spike to carry a heavier load. This in turn improves resistance to lodging and, as a result, allows for an increase in the density of standing through a higher seeding rate, ultimately generating increased grain yield per unit area. In our experiments in both Moscow and Krasnodar, the decrease in plant height in spring wheat due to $R h t-B 1 p$ was very strong (about $30 \%$ ) and the additional effects of the VRN-B1 and Ppd-D1 alleles on plant height (even when statistically significant) do not change the overall effect of the gene. In this regard, the mutual influence of Rht-B1p, VRN-B1 and Ppd-D1 on productivity elements is of particular interest.

The negative effects of dwarfing alleles can be overcome by combining them with alleles of vernalization and day length sensitivity. The length of the straw is a function of the rate of development of the plant, which depends on the response of tissues to hormones and environmental signals (day length, temperature). Different combinations of alleles from genes regulating these reactions can be made to fine-tune developmental phases and achieve maximum plant productivity. The strategy of choosing the right combination of genes should be developed for each region individually.

For Moscow, the most promising option for selection of semi-dwarf productive plants will be a combination of $R h t-B 1 p+P p d-D 1 b$. For Krasnodar, a promising option for selection of semi-dwarf productive plants will be a combination of $R h t-B 1 p+P p d-D 1 a$. It follows from the following results: i) with different confidence probability $P p d-D 1 a$ has a rather negative effect on productivity in Moscow and a positive impact in Krasnodar (the results of the analysis of variance); ii) a weak significant negative correlation in Moscow and positive correlation in Krasnodar between the elements of productivity and Ppd-D1a (the results of the regression analysis); and iii) most productive families were in the direction opposite to the $P p d-D 1 a$ vector in Moscow and in the direction of Ppd-Dla in Krasnodar (the results of the PCA analysis).

Differences in the influence of $R h t-B 1 p$ on the grain number per spike in Moscow and Krasnodar can be explained as follows: Moscow is characterized by sodpodzol, humus-poor soils, whereas the soils of Krasnodar are typical chernozems. Probably, the Rht-B1p allele studied by us has a positive effect on the number of grains in plants only at high soil fertility. It should be remembered that during the "Green revolution" dwarfing alleles $R h t-B 1 b$ and $R h t-D 1 b$ were introduced in order to increase yield and lodging resistance at high doses of fertilizers, irrigation, and intensive cultivation technology. It is also noteworthy that the positive effects of $R h t-B 1 p$ were manifested in the experiment in Krasnodar only in plants with Ppd-D1a.

In its effect on plant height and productivity elements, $R h t-B 1 p$ is close to $R h t-B 1 e$, which is distributed among $16.5 \%$ of varieties in the southern regions of Russia, as well as among some varieties in Ukraine $[8,10,18]$. Thus, Rht-B1p can also be used on an equal footing with other dwarfing alleles in the breeding of wheat in the Krasnodar Krai.

Thus, Rht-B1p significantly reduces the height of plants, but it can also reduce their productivity. Alleles of genes that regulate developmental type and sensitivity to day length can mitigate unwanted manifestations of $R h t-B 1 p$ in favorable regions. At the same time, in Krasnodar, the interaction of $R h t-B 1 p$ and $P p d-D 1 a$ genes influencing valuable agronomic traits is most pronounced at short day length. 


\section{Conclusions}

In summary, we estimated the effects of $R h t-B 1 p$ on plant height and traits of agronomic value in spring bread wheat in Moscow and Krasnodar. Plant height was reduced on average by $21 \mathrm{~cm}(28 \%)$ and $25 \mathrm{~cm}(30 \%)$, respectively, Ppd-D1 tended to strengthen the dwarfing effect in Moscow and mitigate it in Krasnodar. Grain weight per main spike was reduced by $R h t-B 1 p$ in Moscow and to lesser extent in Krasnodar. Thousand grain weight was reduced on average by $5.3 \mathrm{~g}(16 \%)$ and $2.9 \mathrm{~g}(10 \%)$ in Moscow and Krasnodar, respectively. The harvest index was increased due to $R h t-B 1 p$ on average by 6 and 10\% in Moscow and Krasnodar, respectively. In Krasnodar, Ppd-D1a triggered heading 6 days earlier and partially compensated for the loss of grain weight per main spike and thousand grain weight due to $R h t-B 1 p$. Among semi-dwarf plants with $R h t-B 1 p$, the most productive were observed among families with $P p d-D 1 b$ in Moscow and Ppd-D1a in Krasnodar. In its effect on plant height and productivity elements, $R h t-B 1 p$ is close to $R h t-B 1 e$, which is distributed among varieties in the southern regions of Russia and Ukraine. Thus, Rht-B1p can be used on an equal footing with other dwarfing alleles in wheat breeding in the Krasnodar Krai.

\section{Methods}

\section{Plant material}

For the initial plant material, we used seeds of the $F_{2}$ population of Chris Mutant/Novosibirskaya 67, kindly provided by Prof. Nobuyoshi Watanabe (College of Agriculture, Ibaraki University) [7]. The seeds of parental plants Chris Mutant (accession number CItr 17,241) and Novosibirskaya 67 (accession number 48601) are available at Germplasm Research International Network and N.I. Vavilov Research Institute of Plant Industry (VIR) (Saint Petersburg, Russia), respectively. The parental plants were analyzed for the following alleles of $R h t$, $V R N$, and Ppd in their genotypes: Rht-Bla (wild type), $R h t-B 1 b, R h t-B 1 e$, and Rht-B1p for Rht-B1; Rht-D1a (wild type) and Rht-D1b for Rht-D1; Rht-8a (wild type)/ $R h t-8 c$ for Rht-8; vrn-A1, Vrn-A1a, and Vrn-A1b for $V R N A-1$; vrn-B1, Vrn-B1a, and Vrn-B1c for VRN-B1; $v r n-D 1$, and Vrn-D1a for VRN-D1; Ppd-D1a and Ppd$D 1 b$ for Ppd-D1 (see Molecular analysis and Table 6). The following allelic states were revealed: Chris Mutant: Rht-B1p Rht-B1p \crRht-D1a Rht-D1a\crRht-8a Rht8alcrPpd-D1a Ppd-D1alcrVrn-A1a Vrn-A1alcrvrn-B1 vrn-B1 \crvrn-D1 vrn-D1; Novosibirskaya 67: Rht-B1a

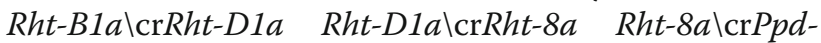
D1b Ppd-D1b \crVrn-A1a Vrn-A1a \crVrn-B1a Vrn$B 1 a \backslash c r v r n-D 1$ vrn-D1. Therefore, the $F_{2}$ population Chris Mutant/Novosibirskaya 67 segregated in the flowing three loci: Rht-B1 (Rht-B1a/Rht-B1p), Ppd-D1 (PpdD1a/PpdD1b), and VRN-B1 (Vrn-B1a/vrn-B1).
The plants of the $F_{2}$ population of Chris Mutant/ Novosibirskaya 67 were planted in pots at 10 seeds per pot and grown in a greenhouse under identical lighting with dosed watering and fertilization. The allelic state of $R h t-B 1$ was identified for each individual $F_{2}$ plant (see Molecular analysis and Table 6). Plants homozygous for $R h t-B 1 p$ and Rht-B1a were selected and threshed manually when they achieved complete ripeness. Seeds of $F_{3}$, harvested from individual $\mathrm{F}_{2}$ plants, were labelled as a single family. Each family was divided into two equal parts and sown in two climatic regions in field plot tests, in Moscow and Krasnodar. During growth, for each individual $\mathrm{F}_{3}$ plant the allelic state of $R h t-B 1, V R N-B 1$ и $P p d-D 1$ was identified using molecular markers (see $M o$ lecular analysis and Table 6).

\section{Molecular analysis}

Genomic DNA was extracted from leaves using a CTAB method [73]. PCR was performed in a $25 \mu \mathrm{L}$ reaction volume, containing $70 \mathrm{mM}$ Tris- $\mathrm{HCl}$ buffer ( $\mathrm{pH} 8.6$ ), $16.6 \mathrm{mM}(\mathrm{NH} 4)_{2} \mathrm{SO}_{4}, 2.5 \mathrm{mM} \mathrm{MgCl}_{2}, 0.2 \mathrm{mM}$ of each $\mathrm{dNTP}, 10 \% \mathrm{v} / \mathrm{v}$ dimethyl sulfoxide, $0.3 \mu \mathrm{M}$ forward and reverse primers (Sintol Ltd., Moscow, Russia), 1.25 U of Coloured Taq-polymerase (Sileks Ltd., Moscow, Russia) and $100 \mathrm{ng}$ of template DNA. The PCR conditions were as recommended by the authors of the molecular markers (Table 6). The PCR reaction was performed in a GeneAmp PCR System 9700 (Applied Biosystems, Foster City, California, USA). The PCR products were separated in a $1.5 \%$ agarose gel in TBE buffer using GeneRuler $100 \mathrm{bp}$ DNA Ladder (Thermo Fisher Scientific, Waltham, Massachusetts, USA) as a molecular weight marker, and stained with ethidium bromide for subsequent visualization in Gel Doc XR+ (Bio-Rad Laboratories, Inc., Hercules, California, USA). The size of the PCR products amplified from molecular marker Xgwm261, linked to $R h t-8$, were measured using fragment analysis in a Genetic Analyzer ABI-3130XL (Applied Biosystems, Foster City, California, USA).

\section{Field experiment}

The field experiment was performed in the Field Experimental Station, Russian State Agrarian UniversityMoscow Timiryazev Agricultural Academy, Moscow $\left(55^{\circ} 50^{\prime} \mathrm{N}, 37^{\circ} 33^{\prime} \mathrm{E}\right.$, hereinafter - Moscow) and in a plot of land at the National center of grain named after P.P. Lukyanenko in Krasnodar $\left(45^{\circ} .41^{\prime} \mathrm{N}, 38^{\circ} .55^{\prime} \mathrm{E}\right.$, hereafter referred to as Krasnodar) in 2018. The duration of daylight in Moscow was 15:35 at sowing day (May 5), increasing to $17: 33$ (June 24) and decreasing to $14: 49$ at the final date of harvesting (August 8); the average daylight duration was 16:40 (long photoperiod). The duration of daylight in Krasnodar was 12:10 at sowing day (March 21) which increased to 15:34 at the final date of 
Table 6 Description of the molecular markers applied in the study for the identification of the allelic state of Rht, VRN and Ppd genes

\begin{tabular}{|c|c|c|c|c|}
\hline Gene & Primer sequence & Allele & Expected size of the product, bp & Reference \\
\hline \multirow[t]{6}{*}{$R h t-B 1$} & $\begin{array}{l}\text { Rht-B1p-WF: } \\
\text { 5' ACATGGCGGACGTGGTGC 3' } \\
\text { Rht-B1-R1: } \\
\text { 5' GCCGAGAGAGGACGAT 3' }\end{array}$ & Rht-Bla & 425 & {$[7,66]$} \\
\hline & $\begin{array}{l}\text { Rht-B1p-F: } \\
\text { 5' ACATGGCGGACGTGGTGT 3' } \\
\text { Rht-B1-R1: } \\
\text { 5' GCCGAGAGAGGACGAT 3' }\end{array}$ & $\begin{array}{l}\text { Rht-B1p } \\
(\text { Rht17) }\end{array}$ & 425 & \\
\hline & $\begin{array}{l}\text { BF: } \\
\text { 5' GGTAGGGAGGCGAGAGGCGAG 3' } \\
\text { WR1: } \\
\text { CATCCCCATGGCCATCTCGAGCTG }\end{array}$ & Rht-Bla & 237 & [67] \\
\hline & $\begin{array}{l}\text { BF: } \\
\text { 5' GGTAGGGAGGCGAGAGGCGAG 3' } \\
\text { MR1: } \\
\text { 5' CATCCCCATGGCCATCTCGAGCTA 3' }\end{array}$ & $\begin{array}{l}\text { Rht-B1ba } \\
\text { (Rht1) }\end{array}$ & 237 & \\
\hline & $\begin{array}{l}\text { BF: } \\
\text { 5' GGTAGGGAGGCGAGAGGCGAG 3' } \\
\text { W3: } \\
\text { 5' GGCCATCTCCAGCTGCTCCAGCTT 3' }\end{array}$ & Rht-Bla & 228 & [66] \\
\hline & $\begin{array}{l}\text { BF: } \\
\text { 5' GGTAGGGAGGCGAGAGGCGAG 3' } \\
\text { M3: } \\
\text { 5' GGCCATCTCCAGCTGCTCCAGCTA 3' }\end{array}$ & $\begin{array}{l}\text { Rht-Ble } \\
\text { (Rht11) }\end{array}$ & 228 & \\
\hline \multirow[t]{2}{*}{ Rht-D1 } & $\begin{array}{l}\text { DF2: } \\
\text { 5'- GGCAAGCAAAAGCTTCGCG -3' } \\
\text { WR2: } \\
\text { 5'- GGCCATCTCGAGCTGCAC -3' }\end{array}$ & Rht-Dla & 264 & [67] \\
\hline & $\begin{array}{l}\text { DF: } \\
\text { 5'- CGCGCAATTATTGGCCAGAGATAG - 3' } \\
\text { MR2: } \\
\text { 5'- CCCCATGGCCATCTCGAGCTGCTA - 3' }\end{array}$ & $\begin{array}{l}\text { Rht-D1b } \\
(R h t 2)\end{array}$ & 254 & \\
\hline \multirow[t]{2}{*}{ Ppd-D1 } & \multirow{2}{*}{$\begin{array}{l}\text { Ppd-D1_F: } \\
\text { ACGCCTCCCACTACACTG } \\
\text { Ppd-D1_R2: } \\
\text { CACTGGTGGTAGCTGAGATT } \\
\text { Ppd-D1_R1: } \\
\text { GTTGGTTCAAACAGAGAGC }\end{array}$} & Ppd-Dla & 288 & [68] \\
\hline & & $P p d-D 1 b^{a}$ & 414 & \\
\hline \multirow[t]{3}{*}{ VRN-A1 } & \multirow{2}{*}{$\begin{array}{l}\text { VRN1AF: } \\
\text { GAAAGGAAAAATTCTGCTCG } \\
\text { VRN1-INT1R: } \\
\text { GCAGGAAATCGAAATCGAAG }\end{array}$} & Vrn-Ala & $965+876$ & {$[69,70]$} \\
\hline & & Vrn-A1b & 714 & \\
\hline & $\begin{array}{l}\text { VRN1AF: } \\
\text { GAAAGGAAAAATTCTGCTCG } \\
\text { VRN1-INT1R: } \\
\text { GCAGGAAATCGAAATCGAAG }\end{array}$ & $v r n-A l^{a}$ & 734 & \\
\hline \multirow[t]{3}{*}{$V R N-B 1$} & $\begin{array}{l}\text { Intr1/B/F: } \\
\text { CAAGTGGAACGGTTAGGACA } \\
\text { Intr1/B/R3: } \\
\text { CTCATGCCAAAAATTGAAGATGA }\end{array}$ & Vrn-Bla & 709 & [70] \\
\hline & $\begin{array}{l}\text { Intr1: } \\
\text { ATCATCTTCTCCACCAAGGG } \\
\text { Intr1/B/R3: } \\
\text { CTCATGCCAAAAATTGAAGATGA }\end{array}$ & $\begin{array}{l}V r n-B 1 a \\
\text { Vrn-B1C }\end{array}$ & $\begin{array}{l}1124 \\
737\end{array}$ & [71] \\
\hline & $\begin{array}{l}\text { Intr1/B/F: } \\
\text { CAAGTGGAACGGTTAGGACA } \\
\text { Intr1/B/R4: } \\
\text { CAAATGAAAAGGAATGAGAGCA }\end{array}$ & $v r n-B 1^{a}$ & 1149 & \\
\hline VRN-D1 & Intr1/D/F: & Vrn-D1 & 1671 & [70] \\
\hline
\end{tabular}


Table 6 Description of the molecular markers applied in the study for the identification of the allelic state of Rht, VRN and Ppd genes (Continued)

\begin{tabular}{|c|c|c|c|c|}
\hline Gene & Primer sequence & Allele & Expected size of the product, bp & Reference \\
\hline & $\begin{array}{l}\text { GTTGTCTGCCTCATCAAATCC } \\
\text { Intr1/D/R3: } \\
\text { GGTCACTGGTGGTCTGTGC }\end{array}$ & & & \\
\hline & $\begin{array}{l}\text { Intr1/D/F: } \\
\text { GTGTCTGCCTCATCAAATCC } \\
\text { Intr1/D/R4: } \\
\text { AAATGAAAAGGAACGAGAGCG }\end{array}$ & $v r n-D 1^{a}$ & 997 & \\
\hline Rht-8 & $\begin{array}{l}\text { WMS261-F: } \\
\text { 5'- CTCCCTGTACGCCTAAGGC -3' } \\
\text { WMS261-R: } \\
\text { 5'- CTCGCGCTACTAGCCATTG - 3' }\end{array}$ & Rht-8c & 192 & [72] \\
\hline
\end{tabular}

${ }^{a}$ recessive (or partially recessive) allele

harvesting (June 30); the average duration of a day was 14:23 (short photoperiod). Sowing was performed using a breeding cassette drill SKS-6-10 with the following parameters: length of plot $1 \mathrm{~m}$; width of plot, $90 \mathrm{~cm}$; width between the rows, $30 \mathrm{~cm}$ (Moscow) or $40 \mathrm{~cm}$ (Krasnodar); and distance between the plots, $50 \mathrm{~cm}$. Individual plants were labelled and one leaf from each plant was used for DNA extraction to determine the allelic state of $V R N-B 1$ and $P p d-D 1$, as well as for verification of the allelic state of Rht-B1 (see Molecular analysis and Table 6). The plots were treated with pesticides to control pests, the weeds were removed manually. Plants of each family were harvested manually at complete ripeness (August 8 in Moscow and June 30 in Krasnodar). The spikes were threshed using a spike thresher MKS-1 M (MZOK Company, Moscow, Russia). The weather conditions in 2018 in Moscow and Krasnodar are displayed in Table 7.

\section{Phenotyping}

In total, 82 families (1035 plants) and 73 families (731 plants) were analyzed in Moscow and Krasnodar, respectively. The following traits were measured in each individual plant: plant height $(\mathrm{PH}, \mathrm{cm})$, length of each internode $(\mathrm{cm})$, internode number (IN), main spike length (MSL, cm), spikelet number per main spike (SN), main spike weight (MSW, g), main culm weight (MCW, g), grain weight per main spike (GW, g), and grain number per main spike (GN). The following parameters were calculated for each individual plant: spike compactness (SC, number of spikelets per $10 \mathrm{~cm}$ of main spike length), main shoot biomass (MSB, sum of MSW and $\mathrm{MCW}, \mathrm{g}$ ), grain number per spikelet (GNS, GN divided by $\mathrm{SN}$ ), thousand grain weight (W, thousandfold GWS divided by GNS, g), and harvest index (HI, GW divided by MSB). The heading date was recorded for each family when not less than $80 \%$ of the plants came to heading, and based on this date the sum of active $\left(>10^{\circ} \mathrm{C}\right)$ temperatures to heading date $\left(\mathrm{SAT},{ }^{\circ} \mathrm{C}\right)$ and sum of active $(>12 \mathrm{~h}$ ) light days to heading date (SAD, h) were calculated. The seeds were counted with the use of a Seed Counter [74].

\section{Statistical analysis}

For each phenotypic trait the mean value and confidence interval at a level of significance of 0.01 were calculated. The statistical evaluation of the data was carried out by three one-way ANOVA analyses for each locus (Rht-B1, $V R N-B 1$, and $P p d-D 1$ ) and by two two-way ANOVA analyses for the pairwise interaction between loci (Rht$B 1$ and $V R N-B 1$, Rht-B1 and $P p d-D 1)$. The comparisons

Table 7 Temperature and precipitation during the field experiment in Moscow and Krasnodar in 2018

\begin{tabular}{|c|c|c|c|c|c|c|}
\hline \multirow[t]{2}{*}{ Month } & \multicolumn{3}{|l|}{$\begin{array}{l}\text { Moscow } \\
\text { May } 5 \text { - August } 19\end{array}$} & \multicolumn{3}{|l|}{$\begin{array}{l}\text { Krasnodar } \\
\text { March } 21 \text { - June } 30\end{array}$} \\
\hline & $\begin{array}{l}\text { Sum of active }\left(>10^{\circ} \mathrm{C}\right) \\
\text { temperatures, }{ }^{\circ} \mathrm{C}\end{array}$ & $\begin{array}{l}\text { Mean monthly } \\
\text { temperature, }{ }^{\circ} \mathrm{C}\end{array}$ & Sum of precipitation, $\mathrm{mm}$ & $\begin{array}{l}\text { Sum of active }\left(>10^{\circ} \mathrm{C}\right) \\
\text { temperatures, }{ }^{\circ} \mathrm{C}\end{array}$ & $\begin{array}{l}\text { Mean monthly } \\
\text { temperature, }{ }^{\circ} \mathrm{C}\end{array}$ & Sum of precipitation, $\mathrm{mm}$ \\
\hline March & - & - & - & 142 & 6.4 & 38 \\
\hline April & - & - & - & 2845 & 13.8 & 26 \\
\hline May & 3288 & 16.1 & 105 & 4731 & 19.4 & 43 \\
\hline June & 3914 & 17.3 & 107 & 5407 & 24.1 & 11 \\
\hline July & 5097 & 20.5 & 190 & & - & - \\
\hline August & 2926 & 20.3 & 39 & & - & - \\
\hline Total & 15,225 & - & 441 & 13,125 & - & 118 \\
\hline
\end{tabular}


between means were detected using a least significant differences (LSD) test at the level of significance of 0.01 and 0.05 (for heading time). Pairwise comparisons of the interaction between $R h t-B 1$ and $V R N-B 1$ were performed among families homozygous for the photoperiod-insensitive allele Ppd-D1a. Pairwise comparisons of the interaction between Rht-B1 and $P p d-D 1$ were performed among families homozygous for the Vrn-B1a allele. ANOVA, Correlation and Principal Components Analysis were performed using Statistica 12.0 software (StatSoft, Inc., Tulsa, Oklahoma, USA).

\section{Supplementary information}

Supplementary information accompanies this paper at https://doi.org/10. 1186/s12870-020-02514-0.

Additional file 1: Table S1. Mean values of biometric traits for the main shoot in families $F_{3: 4}$ Chris Mutant/Novosibirskaya 67 grouped by Rht-B1, VRN-B1, and Ppd-D1 alleles. Table S2. Mean values of biometric traits of spike productivity traits in families $F_{3: 4}$ Chris Mutant/ Novosibirskaya 67 grouped by Rht-B1, VRN-B1, and Ppd-D1 alleles. Table S3. Mean values of harvest index and main spike traits in families $F_{3: 4}$ Chris Mutant/Novosibirskaya 67 grouped by Rht-B1, VRN-B1, and Ppd-D1 alleles (upper part, one-way NOVA) and by Rht-B1 $\times$ VRN-B1 and Rht-B1 $\times$ Ppd-D1 alleles (lower part, two-way ANOVA). Table S4. Mean values of heading date, sum of active $\left(>10^{\circ} \mathrm{C}\right)$ temperatures and active $(>12 \mathrm{~h})$ light days from sowing to heading date in families $\mathrm{F}_{3: 4}$ Chris Mutant/ Novosibirskaya 67 grouped by Rht-B1, VRN-B1, and Ppd-D1 alleles. Table S5. Mean values of spike parameters in families $F_{3: 4}$ Chris Mutant/Novosibirskaya 67 grouped by Rht-B1, VRN-B1, and Ppd-D1 alleles (upper part, one-way ANOVA) and by $R h t-B 1 \times V R N-B 1$ and $R h t-B 1 \times P p d-D 1$ alleles (lower part, two-way ANOVA).

\section{Abbreviations}

GA: Gibberellic acid; R: Rht-B1a; r: Rht-B1p; V: Vrn-B1a; v: vrn-B1; P: Ppd-D1a; p: Ppd-D1b; PH: Plant height; IN: Internode number; MSL: Main spike length; SN: Spikelet number per main spike; MSW: Main spike weight; MCW: Main culm weight; GW: Grain weight per main spike; GN: Grain number per main spike; SC: Spike compactness; MSB: Main shoot biomass; GNS: Grain number per spikelet; W: Thousand grain weight; HI: Harvest index; SAT: Sum of active $\left(>10^{\circ} \mathrm{C}\right)$ temperatures to heading date; SAD: Sum of active $(>12 \mathrm{~h})$ light days to heading date

\section{Acknowledgements}

We are grateful to Carly Schramm for critical review of the manuscript.

\section{About this supplement}

This article has been published as part of BMC Plant Biology Volume 20 Supplement 1, 2020: Selected articles from the 5th International Scientific Conference "Plant genetics, genomics, bioinformatics, and biotechnology" (PlantGen2019). The full contents of the supplement are available online at https://bmcplantbiol.biomedcentral.com/articles/supplements/volume-20supplement-1.

\section{Authors' contributions}

MGD made the conception of the work and designed the experiments. AGC, WP, LAN, VYK, and EAS performed the experiments. NW helped with the plant material acquisition. PYK, MSB, AGC, and MGD conducted data analysis and contributed towards writing the manuscript. LAB and EAS helped in interpreting results. MGD and GIK supervised the findings of the work. PYK, GIK, LAB, EAS, AGC, NW, MSB, WP, LAN, VYK, MGD have read and approved the manuscript.

\section{Funding}

This research was funded by the Russian Science Foundation, grant number 17-76-20023 in the part of performing field experiments, phenotyping, statistical analysis, and molecular analysis of the allelic state of the Rht dwarfing genes; Kurchatov Genomics Center of IC\&G, agreement № 075-152019-1662 in the part of molecular analysis of the allelic state of the VRN vernalization genes; Kurchatov Genomics Center of All-Russia Research Institute of Agricultural Biotechnology, agreement № 075-15-2019-1667 in the part of molecular analysis of the allelic state of the Ppd photoperiodresponse genes. Publication costs have been funded by the Russian Science Foundation, grant number 17-76-20023. The funders had no role in the experiment design, data analysis, decision to publish or preparation of the manuscript.

\section{Availability of data and materials}

All data generated or analysed during this study are included in this published article and Additional file 1. The seeds of the parental plant Chris Mutant are available at Germplasm Research International Network (https:// npgsweb.ars-grin.gov/gringlobal/search.aspx, accession number Cltr 17241); the seeds of the parental plant Novosibirskaya 67 are available at N.I. Vavilov Research Institute of Plant Industry (VIR), Saint Petersburg, Russia (http://db. vir.nw.ru/virdb/maindb, accession number 48601). The studied recombinant isogenic families with different allelic combinations of the allelic state of $R h t$ B1 (Rht-B1a/Rht-B1p), PpdD1 (PpdD1a/PpdD1b), and VRN-B1 (Vrn-B1a/vrn-B1) loci designated M17/1-M17/81 are being maintained and available upon request from All-Russia Research Institute Of Agricultural Biotechnology (iab@iab.ac.ru, divashuk@gmail.com) and at the National center of grain named after P.P. Lukyanenko (kniish@kniish.ru).

Ethics approval and consent to participate

Not applicable.

\section{Consent for publication}

Not applicable.

\section{Competing interests}

The authors declare that they have no competing interests.

\section{Author details}

${ }^{1}$ Laboratory of Applied Genomics and Crop Breeding, All-Russia Research Institute of Agricultural Biotechnology, Timiryazevskaya str. 42, Moscow 127550, Russia. ${ }^{2}$ Centre for Molecular Biotechnology, Russian State Agrarian University-Moscow Timiryazev Agricultural Academy, Timiryazevskaya street, 49, Moscow 127550, Russia. ${ }^{3}$ Department of Breeding and Seed Production of Wheat and Triticale, National center of grain named after P.P. Lukyanenko, Central Estate of KNIISH, Krasnodar 350012, Russia. ${ }^{4}$ Kurchatov Genomics Center, Institute of Cytology and Genetics SB RAS, Prospekt Lavrentyeva 10, Novosibirsk 630090, Russia. ${ }^{5}$ College of Agriculture, Ibaraki University, 3-21-1 Chuo, Ami, Inashiki, Ibaraki 300-0393, Japan. ${ }^{6}$ Kurchatov Genomics Center-ARRIAB, All-Russia Research Institute of Agricultural Biotechnology, Timiryazevskaya str. 42, Moscow 127550, Russia.

Received: 4 September 2019 Accepted: 22 June 2020

Published online: 14 October 2020

\section{References}

1. Hauvermale AL, Ariizumi T, Steber CM. Gibberellin signaling: a theme and variations on DELLA repression. Plant Physiol. 2012;160(1):83-92.

2. Li A, Yang W, Lou X, Liu D, Sun J, Guo X, et al. Novel natural allelic variations at the Rht-1 loci in wheat. J Integr Plant Biol. 2013;55(11):1026-37.

3. Lou X, Li X, Li A, Pu M, Shoaib M, Liu D, et al. The 160 bp insertion in the promoter of Rht-B1i plays a vital role in increasing wheat height. Front Plant Sci. 2016;7:307.

4. Thomas SG. Novel Rht-1 dwarfing genes: tools for wheat breeding and dissecting the function of DELLA proteins. J Exp Bot. 2017;68(3):354-8.

5. Watanabe N. Genetic collection and development of near-isogenic lines in durum wheat. J VOGiS. 2008;12:636-43.

6. Peng J, Richards DE, Hartley NM, Murphy GP, Devos KM, Flintham JE, et al. 'Green revolution' genes encode mutant gibberellin response modulators. Nature. 1999:400(6741):256-61.

7. Bazhenov MS, Divashuk MG, Amagai Y, Watanabe N, Karlov Gl. Isolation of the dwarfing Rht-B1p (Rht17) gene from wheat and the development of an allele-specific PCR marker. Mol Breed. 2015;35(11):213. 
8. Divashuk MG, Bespalova LA, Vasilyev AV, Fesenko IA, Puzyrnaya OY, Karlov Gl. Reduced height genes and their importance in winter wheat cultivars grown in southern Russia. Euphytica. 2012;190(1):137-44.

9. Wilhelm EP, Boulton MI, Al-Kaff N, Balfourier F, Bordes J, Greenland AJ, et al. Rht-1 and Ppd-D1 associations with height, GA sensitivity, and days to heading in a worldwide bread wheat collection. Theor Appl Genet. 2013; 126(9):2233-43.

10. Chebotar GA, Chebotar SV, Motsnyy II. Pleiotropic effects of gibberellinsensitive and giberrellin-insensitive dwarfing genes in bread wheat of the southern step region of the Black Sea. Cytol Genet. 2016;50(1):20-7.

11. Flintham JE, Börner A, Worland AJ, Gale MD. Optimizing wheat grain yield: effects of Rht (gibberellin-insensitive) dwarfing genes. J Agric Sci. 1997; 128(1):11-25.

12. Miedaner $\mathrm{T}$, Voss $\mathrm{H}$. Effect of dwarfing Rht genes on Fusarium head blight resistance in two sets of near-isogenic lines of wheat and check cultivars. Crop Sci. 2008;48(6):2115.

13. Mathews KL, Chapman SC, Trethowan R, Singh RP, Crossa J, Pfeiffer W, et al. Global adaptation of spring bread and durum wheat lines near-isogenic for major reduced height genes. Crop Sci. 2006;46(2):603.

14. Rebetzke G, Ellis M, Bonnett D, Mickelson B, Condon A, Richards R. Height reduction and agronomic performance for selected gibberellin-responsive dwarfing genes in bread wheat (Triticum aestivum L.). Field Crops Res. 2012; 126:87-96.

15. Liu Y, Zhang J, Hu Y, Chen J. Dwarfing genes Rht4 and Rht-B1b affect plant height and key agronomic traits in common wheat under two water regimes. Field Crop Res. 2017;204:242-8.

16. Ganeva G, Korzun V, Landjeva S, Tsenov N, Atanasova M. Identification, distribution and effects on agronomic traits of the semi-dwarfing Rht alleles in Bulgarian common wheat cultivars. Euphytica. 2005;145(3):305-15.

17. Chebotar GA, Motsnyy II, Chebotar SV, Sivolap YM. Effects of dwarfing genes on the genetic background of wheat varieties in southern Ukraine. Cytol Genet. 2012;46(6):366-72.

18. Bespalova LA, Vasilyev AV, Ablova IB, Filobok VA, Khudokormova ZN, Davoyan $E R$, et al. The use of molecular markers in wheat breeding at the Lukyanenko agricultural research institute. Russian J Genetics. 2012;2(4):286-90.

19. Ellis MH, Rebetzke GJ, Chandler P, Bonnett D, Spielmeyer W, Richards R. The effect of different height reducing genes on the early growth of wheat. Funct Plant Biol. 2004;31(6):583.

20. Gale MD, Youssefian S. Dwarfing genes of wheat. Progress Plant Breed. 1985;1:1-35.

21. Konzak CF. Mutations and mutation breeding. In: Heyne EG (ed) Wheat and wheat improvement. 2nd ed. Madison: Wisconsin: American Society of Agronomy, Inc., Crop Science Society of America, Inc. and Soil Science Society of America, Inc; 1987. p. 428-43.

22. Motsnyy II, Goncharova Al, Chebotar GO, Chebotar SV. Degree of phenotypic dominance and heritability of the plant height in wheat hybrids with different alleles of Rht genes. Cytol Genet. 2017;51(1):18-25.

23. Borrell AK, Incoll LD, Dalling MJ. The influence of the Rht 1 and Rht2 alleles on the growth of wheat stems and ears. Ann Bot. 1991;67(2):103-10.

24. Trethowan R, Singh R, Huerta-Espino J, Crossa J, van Ginkel M. Coleoptile length variation of near-isogenic Rht lines of modern CIMMYT bread and durum wheats. Field Crop Res. 2001;70(3):167-76.

25. Tang N, Jiang Y, He B, Hu Y. The effects of dwarfing genes (Rht-B1b, Rht$D 16$, and Rht8) with different sensitivity to GA3 on the coleoptile length and plant height of wheat. Agric Sci China. 2009;8(9):1028-38.

26. Li P, Chen J, Wu P, Zhang J, Chu C, See D, et al. Quantitative trait loci analysis for the effect of dwarfing gene on coleoptile length and seedling root length and number of bread wheat. Crop Sci. 2011;51(6):2561.

27. Butler JD, Byrne PF, Mohammadi V, Chapman PL, Haley SD. Agronomic performance of alleles in a spring wheat population across a range of moisture levels. Crop Sci. 2005;45(3):939.

28. Snape JW, Butterworth K, Whitechurch E, Worland AJ. Waiting for fine times: genetics of flowering time in wheat. Wheat in a Global Environment. 2001;9: 67-74.

29. Distelfeld A, Li C, Dubcovsky J. Regulation of flowering in temperate cereals. Curr Opin Plant Biol. 2009;12(2):178-84.

30. Kamran A, lqbal M, Spaner D. Flowering time in wheat (Triticum aestivum L.): a key factor for global adaptability. Euphytica. 2014;197(1):1-26.

31. Trevaskis B, Bagnall DJ, Ellis MH, Peacock WJ, Dennis ES. MADS box genes control vernalization-induced flowering in cereals. Proc Natl Acad Sci. 2003; 100(22):13099-104
32. Eagles H, Cane K, Trevaskis B, Vallance N, Eastwood R, Gororo N, et al. Ppd1, Vrn1, ALMT1 and Rht genes and their effects on grain yield in lower rainfall environments in southern Australia. Crop Pasture Sci. 2014;65(2):159.

33. Chen F, Gao M, Zhang J, Zuo A, Shang X, Cui D. Molecular characterization of vernalization and response genes in bread wheat from the yellow and Huai Valley of China. BMC Plant Biol. 2013;13(1):199.

34. Shcherban A, Khlestkina E, Efremova T, Salina E. The effect of two differentially expressed wheat VRN-B1 alleles on the heading time is associated with structural variation in the first intron. Genetica. 2013;141(46):133-41.

35. Muterko A, Salina E. Divergence of VRN-B3 alleles during the evolution of domesticated wheat. Mol Gen Genomics. 2018;294(1):263-75.

36. Zhang B, Wang X, Wang X, Ma L, Wang Z, Zhang X. Molecular characterization of a novel vernalization allele V rn-B1d and its effect on heading time in Chinese wheat (Triticum aestivum L.) landrace Hongchunmai. Mol Breed. 2018;38(10):127.

37. Shcherban AB, Börner A, Salina EA. Effect of VRN-1 and PPD-D1 genes on heading time in European bread wheat cultivars. Plant Breed. 2014;134(1): 49-55.

38. Likhenko IE, Stasyuk Al, Shcherban' AB, Zyryanova AF, Likhenko NI, Salina EA. Study of allelic composition of Vrn-1 and Ppd-1 genes in early-ripening and middle-early varieties of spring soft wheat in Siberia. Russian J Genetics. 2015;5(3):198-207.

39. Whittal A, Kaviani M, Graf R, Humphreys G, Navabi A. Allelic variation of vernalization and photoperiod response genes in a diverse set of north American high latitude winter wheat genotypes. PLoS One. 2018;13(8): e0203068.

40. Kitagawa S, Shimada S, Murai K. Effect of Ppd-1 on the expression of flowering-time genes in vegetative and reproductive growth stages of wheat. Genes Genet Syst. 2012;87:161-8.

41. Shaw LM, Turner AS, Laurie DA. The impact of photoperiod insensitive Ppd1a mutations on the photoperiod pathway across the three genomes of hexaploid wheat (Triticum aestivum). Plant J. 2012;71:71-84.

42. Kiseleva A, Potokina E, Salina E. Features of Ppd-B1 expression regulation and their impact on the flowering time of wheat near-isogenic lines. BMC Plant Biol. 2017:17(S1):172.

43. Worland AJ, Korzun V, Röder MS, Ganal MW, Law CN. Genetic analysis of the dwarfing gene Rht8 in wheat. Part II. The distribution and adaptive significance of allelic variants at the Rht8 locus of wheat as revealed by microsatellite screening. Theor Appl Genet. 1998;96(8):1110-20.

44. Blake N, Lanning S, Martin J, Doyle M, Sherman J, Naruoka Y, et al. Effect of variation for major growth habit genes on maturity and yield in five spring wheat populations. Crop Sci. 2009;49(4):1211.

45. Díaz A, Zikhali M, Turner A, Isaac P, Laurie D. Copy number variation affecting the photoperiod-B1 and Vernalization-A1 genes is associated with altered flowering time in wheat (Triticum aestivum). PLoS One. 2012;7(3): e33234.

46. Boden S, Cavanagh C, Cullis B, Ramm K, Greenwood J, Jean Finnegan E, et al. Ppd-1 is a key regulator of inflorescence architecture and paired spikelet development in wheat. Nature Plants. 2015;1(2):1-6.

47. Würschum T, Langer SM, Longin CF, Tucker MR, Leiser WL. A threecomponent system incorporating Ppd-D1, copy number variation at Ppd-B1, and numerous small-effect quantitative trait loci facilitates adaptation of heading time in winter wheat cultivars of worldwide origin. Plant Cell Environ. 2018;41(6):1407-16.

48. Iqbal M, Navabi A, Yang R, Salmon DF, Spaner D. The effect of vernalization genes on earliness and related agronomic traits of spring wheat in northern growing regions. Crop Sci. 2007;47(3):1031.

49. Chen H, Moakhar NP, lqbal M, Pozniak C, Hucl P, Spaner D. Genetic variation for flowering time and height reducing genes and important traits in western Canadian spring wheat. Euphytica. 2015;208(2):377-90.

50. Chen L, Du Y, Lu Q, Chen H, Meng R, Cui C, et al. The photoperiodinsensitive allele Ppd-D1a promotes earlier flowering in Rht12 dwarf plants of bread wheat. Front Plant Sci. 2018;9:1312.

51. Chen L, Yang Y, Cui C, Lu S, Lu Q, Du Y, et al. Effects of Vrn-B1 and Ppd-D1 on developmental and agronomic traits in Rht5 dwarf plants of bread wheat. Field Crop Res. 2018;219:24-32.

52. Garcia M, Eckermann P, Haefele S, Satija S, Sznajder B, Timmins A, Baumann $U$, Wolters P, Mather D, Fleury D. Genome-wide association mapping of grain yield in a diverse collection of spring wheat (Triticum aestivum L.) evaluated in southern Australia. PLoS One. 2019;14(2):e0211730. 
53. Zhao J, Wang Z, Liu H, Zhao J, Li T, Hou J, Zhang X, Hao C. Global status of 47 major wheat loci controlling yield, quality, adaptation and stress resistance selected over the last century. BMC Plant Biol. 2019;19:5.

54. Chapman S, Mathews K, Trethowan R, Singh R. Relationships between height and yield in near-isogenic spring wheats that contrast for major reduced height genes. Euphytica. 2006;157(3):391-7.

55. Rebetzke G, Bonnett D, Ellis M. Combining gibberellic acid-sensitive and insensitive dwarfing genes in breeding of higher-yielding, sesqui-dwarf wheats. Field Crop Res. 2012;127:17-25.

56. Kolev S, Ganeva G, Christov N, Belchev I, Kostov K, Tsenov N, et al. Allele variation in loci for adaptive response and plant height and its effect on grain yield in wheat. Biotechnology Biotechnological Equipment. 2010;24(2):1807-13.

57. Foulkes M, Sylvester-Bradley R, Worland A, Snape J. Effects of a photoperiod-response gene Ppd-D1 on yield potential and drought resistance in UK winter wheat. Euphytica. 2004:135(1):63-73.

58. Guo Z, Song Y, Zhou R, Ren Z, Jia J. Discovery, evaluation and distribution of haplotypes of the wheat Ppd-D1 gene. New Phytol. 2009;185(3):841-51.

59. Prieto P, Ochagavía H, Savin R, Griffiths S, Slafer G. Dynamics of floret initiation/death determining spike fertility in wheat as affected by Ppd genes under field conditions. J Exp Bot. 2018;69(10):2633-45.

60. Li X, Lan S, Liu Y, Gale M, Worland T. Effects of different Rht-B1b, Rht-D1b and Rht-BIC dwarfing genes on agronomic characteristics in wheat. Cereal Res Commun. 2006;34(2-3):919-24.

61. Zanke C, Ling J, Plieske J, Kollers S, Ebmeyer E, Korzun V, et al. Analysis of main effect QTL for thousand grain weight in European winter wheat (Triticum aestivum L.) by genome-wide association mapping. Front Plant Sci. 2015;6:644.

62. Bogard M, Biddulph B, Zheng B, Hayden M, Kuchel H, Mullan D, Allard V, Le Gouis J, Chapman S. Enabling breeding of spring wheat for optimisation of flowering time for current and future climates by linking genetic maps to simulation model parameters. Crop Sci. 2020. https:/doi.org/10.1002/csc2.20113.

63. Chernook AG, Kroupin PY, Karlov GI, Soloviev AA, Korshunova AD, Rubets VS, et al. Effects of Rht-B1b and Ddw1 dwarfing genes in two connecting populations of spring triticale under greenhouse experiment conditions. Agriculture. 2019;9(6):119.

64. Worland A. The influence of flowering time genes on environmental adaptability in European wheats. Euphytica. 1996:89(1):49-57.

65. Bentley AR, Horsnell R, Werner CP, Turner AS, Rose GA, Bedard C, et al. Short, natural, and extended photoperiod response in $\mathrm{BC} 2 \mathrm{~F} 4$ lines of bread wheat with different Photoperiod-1 (Ppd-1) alleles. J Exp Bot. 2013;64(7): 1783-93.

66. Pearce S, Saville R, Vaughan S, Chandler P, Wilhelm E, Sparks C, et al. Molecular characterization of Rht-1 dwarfing genes in hexaploid wheat. Plant Physiol. 2011;157(4):1820-31.

67. Ellis M, Spielmeyer W, Gale K, Rebetzke G, Richards R. "Perfect" markers for the Rht-B1b and Rht-D1b dwarfing genes in wheat. Theor Appl Genet. 2002; 105(6):1038-42.

68. Beales J, Turner A, Griffiths S, Snape J, Laurie D. A pseudo-response regulator is misexpressed in the photoperiod insensitive Ppd-Dla mutant of wheat (Triticum aestivum L.). Theor Appl Genet. 2007;115(5):721-33.

69. Yan L, Helguera M, Kato K, Fukuyama S, Sherman J, Dubcovsky J. Allelic variation at the VRN-1 promoter region in polyploid wheat. Theor Appl Genet. 2004;109(8):1677-86.

70. Fu D, Szücs P, Yan L, Helguera M, Skinner J, von Zitzewitz J, et al. Large deletions within the first intron in VRN-1 are associated with spring growth habit in barley and wheat. Mol Gen Genomics. 2005;273(1):54-65.

71. Shcherban A, Efremova T, Salina E. Identification of a new Vrn-B1 allele using two near-isogenic wheat lines with difference in heading time. Mol Breed. 2011;29(3):675-85

72. Korzun V, Börner A, Worland A, Law C, Röder M. Application of microsatellite markers to distinguish inter-varietal chromosome substitution lines of wheat (Triticum aestivum L.). Euphytica. 1997;95(2):149-55.

73. Bernatzky R, Tanksley S. Genetics of actin-related sequences in tomato. Theor Appl Genet. 1986;72(3):314-21.

74. Komyshev E, Genaev M, Afonnikov D. Evaluation of the SeedCounter, a Mobile application for grain Phenotyping. Front Plant Sci. 2017;7:1990.

\section{Publisher's Note}

Springer Nature remains neutral with regard to jurisdictional claims in published maps and institutional affiliations.

\section{Ready to submit your research? Choose BMC and benefit from}

- fast, convenient online submission

- thorough peer review by experienced researchers in your field

- rapid publication on acceptance

- support for research data, including large and complex data types

- gold Open Access which fosters wider collaboration and increased citations

- maximum visibility for your research: over $100 \mathrm{M}$ website views per year

At $\mathrm{BMC}$, research is always in progress.

Learn more biomedcentral.com/submissions 